Optical Manufacturing and Testing Requirements Identified by the NASA Science Instruments, Observatories and Sensor Systems Technology Assessment

\author{
H. Philip Stahl \\ NASA Marshall Space Flight Center (MSFC), Huntsville, AL
}

In August 2010, the NASA Office of Chief Technologist (OCT) commissioned an assessment of 15 different technology areas of importance to the future of NASA. Technology assessment \#8 (TA8) was Science Instruments, Observatories and Sensor Systems (SIOSS). SIOSS assess the needs for optical technology ranging from detectors to lasers, $\mathrm{x}$-ray mirrors to microwave antenna, in-situ spectrographs for on-surface planetary sample characterization to large space telescopes. The needs assessment looked across the entirety of NASA and not just the Science Mission Directorate. This paper reviews the optical manufacturing and testing technologies identified by SIOSS which require development in order to enable future NASA high priority missions.

SPIE Photonics Meeting

San Diego CA

August 21-25, 2011 


\title{
Optical manufacturing and testing requirements identified by the NASA Science Instruments, Observatories and Sensor Systems Technology Assessment
}

\author{
H. Philip Stahl ${ }^{\mathrm{a}}$, Rich Barney ${ }^{\mathrm{b}}$, Jill Bauman ${ }^{\mathrm{c}}$, Lee Feinberg ${ }^{\mathrm{b}}$, Dan Mccleese ${ }^{\mathrm{d}}$, Upendra Singh ${ }^{\mathrm{e}}$

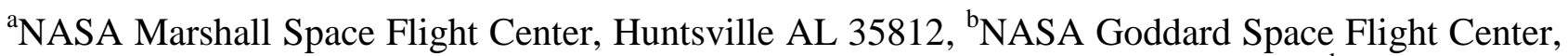 \\ Greenbelt MD 20771; ${ }^{\mathrm{c}}$ NASA Ames Research Center, Moffett Field CA 94035, ${ }^{\mathrm{d}} \mathrm{Jet}$ Propulsion \\ Laboratory, Pasadena CA 91109, ${ }^{\mathrm{d}}$ NASA Langley Research Center, Hampton VA 23681
}

\begin{abstract}
Optical manufacturing and testing technologies are critical to enabling NASA's future high priority missions. A technology assessment roadmap for Science Instruments, Observatories and Sensor Systems (SIOSS) was developed for the NASA Office of Chief Technologist. This roadmap identifies a wide range of specific challenges (including some which require optical manufacturing and testing technology) that require maturation over the next 10 years.
\end{abstract}

Keywords: NASA, Optical Manufacturing Technology, Optical Testing Technology, Technology Development

\section{INTRODUCTION}

In July 2010, NASA's Office of Chief Technologist (OCT) initiated the Aero-Space Technology Area Roadmap study. The purpose of the study is to identify where substantial enhancements in NASA mission capabilities are needed and recommend areas for significant technology investment. The product of this study is technology area integrated roadmaps. These roadmaps provide a critical snapshot of specific challenges and technologies, as well as how these technologies can support NASA's missions and contribute to significant national needs. These reports will be used as a strategic guide to inform the agency's budget formulation and prioritization process; organize OCT solicitations; and initiate an open process of community engagement through a National Research Council (NRC) space technology evaluation and prioritization process.

The primary goal is to develop clear recommendations for technology development programs for NASA's highest priority needs. Each technology assessment must establish the current prioritization of its technology needs; define alternative paths for developing technology to meet those needs; and identify interrelationships between various technologies and their associated development programs. Technology Area \#8 (TA8) is the Science Instruments, Observatory and Sensor Systems (SIOSS) Technology Roadmap. The initial TA8 25-page reports was presented to the NRC for review (http://www.nasa.gov/offices/oct/home/roadmaps/index.html). The NRC reviews are expected in late summer 2011. The final report will provide NASA with strategic guidance and recommendations that will inform future NASA technology investment decisions. These roadmaps will be updated annually and externally reviewed every 4 years to insure consistency with the Agency's Strategic Plans.

Stahl, et. al. (2011) summaries the process by which the SIOSS roadmap was developed and presents the detailed findings for Astrophysics. This paper presents the detailed findings for Observatory technology needs which drive requirements for optical manufacturing and testing technology development. 


\section{SCIENCE INSTRUMENTS, OBSERVATORY AND SENSOR SYSTEMS TECHNOLOGY}

The Science Instruments, Observatories, and Sensor Systems (SIOSS) roadmap address technology needed to achieve NASA's highest priority objectives - not only for the Science Mission Directorate (SMD), but for all of NASA. The SIOSS Team employed a multi-step process. The first step was to perform an SMD needs assessment. SMD organizes its science portfolio along four themes: Astrophysics, Earth Science, Heliophysics, and Planetary Science. The SIOSS roadmap is fully traceable to the Decadal Surveys for Astrophysics, Earth Science, Heliophysics, and Planetary. Technology needs and challenges are defined for either specific planned science missions ('pull technology') or emerging measurement techniques necessary to enable new scientific discovery ('push technology'). A complete list of these documents is in the Bibliography. Using these guidance documents, SIOSS created comprehensive lists, for each SMD Division, of technology needed to enable or enhance planned and potential future missions. These lists were reviewed and refined by individual mission and technology-development stakeholders.

The second step consolidated the identified technology needs into broad categories and organized them into a Technology Area Breakdown Structure (TABS). The state of the art for each TABS area was quantified; capability gaps and overlaps were identified; and needs for future technology development defined. The next step was to generate a 20 year horizon technology development roadmaps for each TABS element. This roadmap includes potential alternative development paths for achieving a given performance goal. The last step investigated interdependencies with other TA Areas as well as the needs of Other Government Agencies.

\subsection{Technology Needs Assessment}

Science Instruments, Observatories, and Sensor Systems (SIOSS) technology needs were assessed for each of NASA's Science Mission Directorate's science Divisions: Astrophysics, Earth Science, Heliophysics, and Planetary Science.

\subsubsection{Astrophysics Technology Needs}

The National Academy 2010 Decadal Report, New Worlds, New Horizons, recommended a suite of missions and technology-development programs to study three compelling Astrophysics science themes: Cosmic Dawn: Searching for the First Stars, Galaxies and Black Holes; New Worlds: Seeking Nearby, Habitable Planets; and Physics of the Universe: Understanding Scientific Principles. The specific missions (all of which can be enhanced or enabled by technology development to reduce cost, schedule, and performance risks) with their potential launch dates (which drive TRL6 need dates) and development programs, are:

- $\quad$ Wide Field Infrared Survey Telescope (WFIRST), 2018

- Explorer Program, 2019/2023

- Laser Interferometer Space Antenna (LISA), 2024

- International X-ray Observatory (IXO), mid/late 2020s

- New Worlds Technology Development Program, mid/late 2020s

- Epoch of Inflation Technology Development Program, mid/late 2020s

- U.S. Contribution to the JAXA-ESA SPICA Mission, 2017

- UV-Optical Space Capability Technology Development Program, mid/late 2020s

- TRL 3-to-5 Intermediate Technology Development Program

In support of these missions, the Decadal made specific technology development funding recommendations, including:

1. Development to reduce cost $\&$ risk of future missions at a level of $\sim 10 \%$ of each mission's anticipated budget;

2. Development to prepare for missions beyond 2020 such as New Worlds, Inflation Probe or a Large UV-Optical Space Telescope;

3. "General" technology to define, mature, and select approaches for future competed missions, and

4. "Blue sky" technology for transformational improvements in capability to enable undreamed of missions. 
Table 1 summarizes the Astrophysics Mission technology needs identified by the Decadal Report and individual mission and technology development stakeholders. These needs require advancements in five generic technology areas:

1. Detectors and electronics for X-ray and UV/optical/infrared (UVOIR);

2. Optical components \& systems for starlight suppression, wavefront control, \& enhanced UVOIR performance;

3. Low-power sub $10 \mathrm{~K}$ cryo-coolers;

4. Large X-ray and UVOIR mirror systems; and

5. Multi-spacecraft formation flying, navigation, and control.

The first column of Table 1 lists the specific potential mission for which a technology is needed. Additionally, it lists 'push' if the technology area of that row was identified as having promise of radically improving measurement capabilities to enable emerging missions. Examples of push technology include: broadband high responsivity detectors; very large pixel array detectors; UVOIR telescopes with a 15 to 30 meter aperture; $x$-ray telescopes with an 8 meter aperture; or 500 meter structural booms. The second column lists the specific technology needed by that mission. The next three columns define: the metric by which the need is quantified, the current state of the art for that metric, and the level to which that technology needs to be developed to enable or enhance future missions. The fifth column gives when technology development needs to begin in order to be at TRL- 6 by the date given in the last column.

In addition to the technologies identified in Table 1, potential Astrophysics missions depend upon several non-SIOSS technologies, including:

- Launch vehicles with affordable volume \& mass capacities to enable missions of all sizes (especially large);

- Terabit communication; and

- micro-Newton thrusters for precision pointing control and formation-flying navigation control.

\subsubsection{Earth Science Technology Needs}

The National Academy 2007 Decadal Report, Earth Science and Applications from Space: National Imperatives for the Next Decade and Beyond, recommended a suite of missions and technology- development programs to study compelling Earth Science themes: Weather, Solid Surface and Interior; Carbon Cycle and Ecosystems; Water and Energy Cycles; Climate Variability and Change; and Atmospheric Composition.

Earth Science Missions use combinations of active and passive remote sensing instruments/sensors to make the desired science measurements. Earth Science missions can benefit from technology maturation to reduce cost, schedule, and performance risks from SIOSS and other technology areas. Earth Science missions require enabling and enhancing technology primarily for microwave and optical instruments:

- Advance antennas, receivers, transmitters, signal- and data-processing electronics, and cryogenic coolers for efficiencies in mass and power for microwave instruments;

- Improve low-areal density telescopes in the 1-m range, filters and coatings; advance low noise/highly efficient detectors, and focal planes with readout integrated circuits (ROIC); complementary detector arrays, electronics, cryogenic coolers and data processing systems and passive hyperspectral/multispectral/imagers, (UV-Vis-IRFIR) and spectrometers ( 0.3 to $50 \mu \mathrm{m})$,

- Advance lasers in 0.3-2.0 $\mu \mathrm{m}$ range (high power, multi-beam/multi-wavelength, pulsed, and continuous wave), detectors, receivers, larger collecting optics, and scanning mechanisms (including pointing and scanning at high angular resolution); improved quantum efficiency detectors, long-life, high-power laser diode arrays; improved high damage threshold optics;

- Large telescope and RF antenna, which are key enablers for future climate and weather applications. 


\begin{tabular}{|c|c|c|c|c|c|c|}
\hline \multicolumn{7}{|c|}{ Table 1: Summary of Astrophysics Technology Needs } \\
\hline Mission & Technology & Metric & State of Art & Need & Start & TRL6 \\
\hline $\begin{array}{l}\text { UVOTP } \\
\text { Push }\end{array}$ & $\begin{array}{l}\text { Detector arrays: } \\
\text { Low noise }\end{array}$ & $\begin{array}{l}\text { Pixel } \\
\text { QE UV } \\
\text { QE Visible } \\
\text { Rad Hard }\end{array}$ & $2 \mathrm{k} \times 2 \mathrm{k}$ & $\begin{array}{l}4 \mathrm{k} \times 4 \mathrm{k} \\
>0.590-300 \mathrm{~nm} \\
>0.8300-900 \mathrm{~nm} \\
50 \text { to } 200 \mathrm{kRad}\end{array}$ & 2012 & 2020 \\
\hline $\begin{array}{l}\text { NWTP } \\
\text { Push }\end{array}$ & Photon counting arrays & $\begin{array}{l}\text { Pixel array visible } \\
\text { Visible QE }\end{array}$ & $\begin{array}{l}512 \times 512 \\
80 \% 450-750 \mathrm{~nm}\end{array}$ & $\begin{array}{l}512 \times 512 \\
>80 \% 450-900 \mathrm{~nm}\end{array}$ & 2011 & 2020 \\
\hline $\begin{array}{l}\text { SPICA } \\
\text { ITP } \\
\text { Push }\end{array}$ & Far-IR detector arrays & $\begin{array}{l}\text { Sens. (NEP W/ } / \sqrt{H z} \text { ) } \\
\text { Wavelength } \\
\text { Pixels }\end{array}$ & $\begin{array}{l}1 \mathrm{e}-18 \\
>250 \mu \mathrm{m} \\
256\end{array}$ & $\begin{array}{l}3 \mathrm{e}-20 \\
35-430 \mu \mathrm{m} \\
1 \mathrm{k} \times 1 \mathrm{k}\end{array}$ & 2011 & $\begin{array}{l}2015 \\
2020\end{array}$ \\
\hline $\begin{array}{l}\text { IXO } \\
\text { Push }\end{array}$ & $\begin{array}{l}\text { X-ray detectors } \\
\text { (Microcalorimeter / } \\
\text { Active pixel sensor) }\end{array}$ & $\begin{array}{l}\text { Pixel array } \\
\text { Pixel size } \\
\text { Energy res @ 6keV } \\
\text { Noise } \\
\text { QE } \\
\text { Count rate/pixel } \\
\text { Frame rate }\end{array}$ & $\begin{array}{l}6 \times 6 / 64 \times 64 \\
300 \mu \mathrm{m} \\
4 \mathrm{eV} \\
10-15 \mathrm{e}^{-} \mathrm{RMS} \\
\\
300 \mathrm{cts} / \mathrm{s} \\
100 \mathrm{kHz} @ 2 \mathrm{e}^{-}\end{array}$ & $\begin{array}{l}40 \mathrm{x} 40 / 1 \mathrm{kx} 1 \mathrm{k} \\
100 \mu \mathrm{m} \\
2 \mathrm{eV} \\
2-4 \mathrm{e}^{-} \mathrm{RMS} \\
>0.70 .3-8 \mathrm{keV} \\
1000 \mathrm{cts} / \mathrm{s} \\
0.5-1 \mathrm{MHz} @ 2 \mathrm{e}\end{array}$ & 2011 & 2015 \\
\hline $\begin{array}{l}\text { WFIRST } \\
\text { IXO }\end{array}$ & Detector ASIC & $\begin{array}{l}\text { Speed @ low noise } \\
\text { Rad tolerance }\end{array}$ & $\begin{array}{l}100 \mathrm{kHz} \\
14 \mathrm{krad}\end{array}$ & $\begin{array}{l}0.5-1 \mathrm{MHz} \\
55 \mathrm{krad}\end{array}$ & 2011 & 2013 \\
\hline NWTP & $\begin{array}{l}\text { Visible Starlight } \\
\text { suppression: } \\
\text { coronagraph or } \\
\text { occulter } \\
\end{array}$ & $\begin{array}{l}\text { Contrast } \\
\text { Contrast stability } \\
\text { Passband } \\
\text { Inner Working Angle }\end{array}$ & $\begin{array}{l}>1 \times 10^{-9} \\
--- \\
10 \%, 760-840 \mathrm{~nm} \\
4 \lambda / \mathrm{D} \\
\end{array}$ & $\begin{array}{l}<1 \times 10^{-10} \\
1 \times 10^{-11} / \text { image } \\
20 \%, \text { at } V, I, \text { and } R \\
2 \lambda / \mathrm{D}-3 \lambda / \mathrm{D} \\
\end{array}$ & 2011 & 2016 \\
\hline NWTP & $\begin{array}{l}\text { Mid-IR Starlight } \\
\text { suppres: interferometer }\end{array}$ & $\begin{array}{l}\text { Contrast } \\
\text { Passband mid-IR }\end{array}$ & $\begin{array}{l}1.65 \times 10^{-8}, \text { laser } \\
30 \% \text { at } 10 \mu \mathrm{m}\end{array}$ & $\begin{array}{l}<1 \times 10^{-7}, \text { broadband } \\
>50 \% 8 \mu \mathrm{m}\end{array}$ & 2011 & 2020 \\
\hline $\begin{array}{l}\text { NWTP } \\
\text { UVOTP }\end{array}$ & $\begin{array}{l}\text { Active WFSC; } \\
\text { Deformable Mirrors }\end{array}$ & $\begin{array}{l}\text { Sensing } \\
\text { Control (Actuators) }\end{array}$ & $\begin{array}{l}\lambda / 10,000 \mathrm{rms} \\
32 \times 32\end{array}$ & $\begin{array}{l}<\lambda / 10,000 \mathrm{rms} \\
128 \times 128\end{array}$ & 2011 & 2020 \\
\hline IXO & XGS CAT grating & Facet size; Throughput & $3 \times 3 \mathrm{~mm} ; 5 \%$ & $60 \times 60 \mathrm{~mm} ; 45 \%$ & 2010 & 2014 \\
\hline Various & Filters \& coatings & Reflect/transmit; temp & & & 2011 & 2020 \\
\hline Various & Spectroscopy & Spectral range/resolve & & & 2011 & 2020 \\
\hline $\begin{array}{l}\text { SPICA } \\
\text { IXO }\end{array}$ & $\begin{array}{l}\text { Continuous sub-K } \\
\text { refrigerator }\end{array}$ & $\begin{array}{l}\text { Heat lift } \\
\text { Duty cycle }\end{array}$ & $\begin{array}{l}<1 \mu \mathrm{W} \\
90 \%\end{array}$ & $\begin{array}{l}>10 \mu \mathrm{W} \\
100 \%\end{array}$ & 2011 & 2015 \\
\hline $\begin{array}{l}\text { IXO } \\
\text { Push }\end{array}$ & $\begin{array}{l}\text { Large X-ray mirror } \\
\text { systems }\end{array}$ & $\begin{array}{l}\text { Effective Area } \\
\text { HPD Resolution } \\
\text { Areal Density; Active }\end{array}$ & $\begin{array}{l}0.3 \mathrm{~m} 2 \\
15 \mathrm{arcsec} \\
10 \mathrm{~kg} / \mathrm{m} 2 ; \mathrm{no}\end{array}$ & $\begin{array}{l}>3 \mathrm{~m} 2(50 \mathrm{~m} 2) \\
<5 \operatorname{arcsec}(<1 \text { as }) \\
1 \mathrm{~kg} / \mathrm{m} 2 ; \text { yes }\end{array}$ & 2011 & $\begin{array}{l}2020 \\
(30)\end{array}$ \\
\hline $\begin{array}{l}\text { UVOTP } \\
\text { Push }\end{array}$ & $\begin{array}{l}\text { Large UVOIR mirror } \\
\text { systems }\end{array}$ & $\begin{array}{l}\text { Aperture diameter } \\
\text { Figure } \\
\text { Stability } \\
\text { Reflectivity } \\
\mathrm{kg} / \mathrm{m} 2 \\
\$ 1 \mathrm{~m} 2 \\
\end{array}$ & $\begin{array}{l}2.4 \mathrm{~m} \\
<10 \mathrm{~nm} \mathrm{rms} \\
--- \\
>60 \%, 120-900 \mathrm{~nm} \\
30 \mathrm{~kg} / \mathrm{m} 2 \\
\$ 12 \mathrm{M} / \mathrm{m} 2\end{array}$ & $\begin{array}{l}3 \text { to } 8 \mathrm{~m}(15 \text { to } 30 \mathrm{~m}) \\
<10 \mathrm{~nm} \mathrm{rms} \\
>9,000 \mathrm{~min} \\
>60 \%, 90-1100 \mathrm{~nm} \\
\text { Depends on } \mathrm{LV} \\
<\$ 1 \mathrm{M} / \mathrm{m} 2\end{array}$ & 2011 & $\begin{array}{c}2020 \\
(30)\end{array}$ \\
\hline WFIRST & Passive stable structure & Thermal stability & Chandra & WFOV PSF Stable & 2011 & 2014 \\
\hline NWTP & Large structure: occulter & Dia; Petal Edge Tol & Not demonstrated & $30-80 \mathrm{~m} ;<0.1 \mathrm{~mm} \mathrm{rms}$ & 2011 & 2016 \\
\hline $\begin{array}{l}\text { NWTP } \\
\text { UVOTP } \\
\text { Push }\end{array}$ & $\begin{array}{l}\text { Large, stable telescope } \\
\text { structures } \\
\text { (Passive or active) }\end{array}$ & $\begin{array}{l}\text { Aperture diameter } \\
\text { Thermal/dynamic WFE } \\
\text { Line-of-sight jitter } \\
\mathrm{kg} / \mathrm{m} 2 \\
\$ / \mathrm{m} 2\end{array}$ & $\begin{array}{l}6.5 \mathrm{~m} \\
60 \mathrm{~nm} \mathrm{rms} \\
1.6 \mathrm{mas} \\
40 \mathrm{~kg} / \mathrm{m} 2 \\
\$ 4 \mathrm{M} / \mathrm{m} 2 \\
\end{array}$ & $\begin{array}{l}8 \mathrm{~m}(15 \text { to } 30 \mathrm{~m}) \\
<0.1 \mathrm{~nm} \text { rms } \\
1 \mathrm{mas} \\
<20(\text { or } 400) \mathrm{kg} / \mathrm{m} 2 \\
<\$ 2 \mathrm{M} / \mathrm{m} 2\end{array}$ & 2011 & $\begin{array}{c}2020 \\
(30)\end{array}$ \\
\hline $\begin{array}{l}\text { LISA } \\
\text { NWTP }\end{array}$ & $\begin{array}{l}\text { Drag-Free Flying } \\
\text { Occulter Flying }\end{array}$ & $\begin{array}{l}\text { Residual accel } \\
\text { Range } \\
\text { Lateral alignment }\end{array}$ & $3 \times 10^{-14} \mathrm{~m} / \mathrm{s}^{2} / \sqrt{\mathrm{Hz}}$ & $\begin{array}{l}3 \times 10^{-15} \mathrm{~m} / \mathrm{s}^{2} / \sqrt{\mathrm{Hz}} \\
10,000 \text { to } 80,000 \mathrm{~km} \\
\pm 0.7 \mathrm{~m} \text { wrt LOS }\end{array}$ & 2011 & 2016 \\
\hline $\begin{array}{l}\text { NWTP } \\
\text { Push }\end{array}$ & $\begin{array}{l}\text { Formation flying: } \\
\text { Sparse \& Interferometer }\end{array}$ & $\begin{array}{l}\text { Position/pointing } \\
\text { \#; Separation }\end{array}$ & $\begin{array}{l}5 \mathrm{~cm} / 6.7 \operatorname{arcmin} \\
2 ; 2 ; 2 \mathrm{~m}\end{array}$ & $5 ; 15-400-\mathrm{m}$ & 2011 & 2020 \\
\hline $\begin{array}{l}\text { LISA } \\
\text { Push }\end{array}$ & $\begin{array}{l}\text { Gravity wave sensor } \\
\text { Atomic interferometer }\end{array}$ & $\begin{array}{l}\text { Spacetime Strain } \\
\text { Bandpass }\end{array}$ & N/A & $\begin{array}{l}1 \times 10^{-21} / \sqrt{\mathrm{Hz}}, 0.1- \\
100 \mathrm{mHZ}\end{array}$ & 2011 & 2019 \\
\hline
\end{tabular}




\subsubsection{Heliophysics Technology Needs}

The 2009 NASA Heliophysics Roadmap, Heliophysics: the Solar and Space Physics of a New Era, contained a scienceand technology-development roadmap for 2009-2030. The science program consists of two strategic mission lines: Solar Terrestrial Probes (STP) and Living with a Star (LWS). As SIOSS was written, the National Academy was preparing a new Decadal, scheduled for publication in 2012. It was not included in preparing the initial SIOSS report.

Heliophysics missions require enabling and enhancing technology development to:

- Improve UV and EUV detectors (sensitivity, solar blindness, array size, and pixel counts);

- Reduce noise and insensitivity of electronics and detectors to heat and radiation;

- Improve UV and EUV optical components (coating reflectivity and polarization uniformity, grating efficiency, and surface figure quality);

- Improve cryo-coolers for IR detectors; and

- Improve in-situ particle sensor-aperture size and composition identification.

Additionally, potential Heliophysics missions are critically dependent upon several non-SIOSS technologies, including:

- In-space propulsion (solar sails and solar electric) for reaching and maintaining orbits;

- Space power and radioisotopes for both near Sun and deep space;

- Terabit communication and data-compression technologies; and

- Affordable volume and mass capacities of launch vehicles.

\subsubsection{Planetary Science Technology Needs}

The National Academy 2003 Solar System Exploration (SSE) Decadal Survey, New Frontiers in the Solar System: An Integrated Exploration Strategy, provided a list of planetary missions and identified the enabling technologies required to support those missions for the decade 2003-2013. When SIOSS was written, the National Academy was preparing a new Decadal planned for release in March 2011. The initial SIOSS report included expected general recommendations for technology development that align with the major flight programs within the Planetary Science Division (PSD): Discovery, New Frontiers, Lunar Quest, Mars Exploration, and Outer Planets Programs.

Planetary Science missions further our understanding of the Solar System and characterize the surface and environments of targets for future human exploration. They require technology advances that:

- Reduce technical, cost, schedule, and performance risk;

- Support a wide range of probable target bodies (e.g. planets, moons, asteroids, comets)

$\circ$ diverse size, shape, and rotation rate;

- absolute temperature and thermal variations;

- surface composition, topography and activity;

- atmospheric densities, cloud cover, gas composition, and corrosiveness;

- solar intensities and radiation environment;

- magnetic and gravitational fields;

- Planetary-protection measures.

Planetary Science missions enabling and enhancing technology requirements include:

- Sensors, optics, electronics capable of operating in extreme environments; and

- Sampling systems

Additionally, potential Planetary missions are critically dependent upon several non-SIOSS technologies, including: propulsion systems for sample return. 


\subsection{Technology Area Breakdown Structure (TABS)}

The technology need assessments for each SMD area (Astrophysics, Earth Science, Heliophysics and Planetary) were deconstructed into broad categories. For example, many missions require new or improved large aperture telescopes. These needs were organized into a three category, 4-level Technology Area Breakdown Structure (TABS). The three main categories are: Remote Sensing Instruments/Sensors, Observatories, and In-situ Instruments/Sensors (Figure 1).

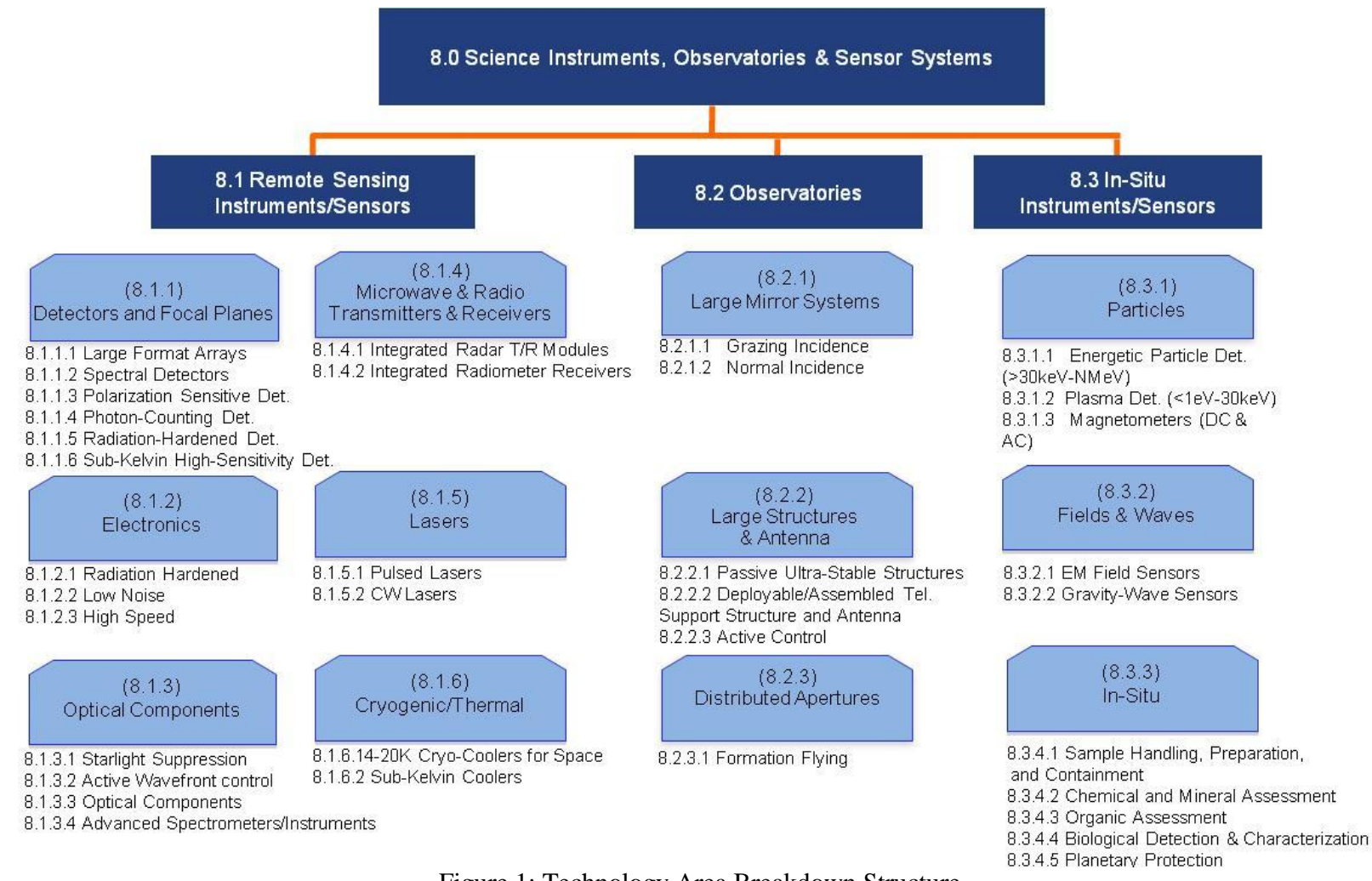

Figure 1: Technology Area Breakdown Structure

Remote Sensing Instruments/Sensors includes components, sensors, and instruments which convert electromagnetic radiation (photons or waves) into science data or generate electromagnetic radiation (photons or waves). Observatory includes components required to build systems that collect, concentrate, and/or transmit photons. In-situ Instruments/Sensors includes components, sensors, and instruments which create science data from fields or waves (AC or DC electromagnetic, gravity, acoustic, seismic, etc); particles (charged, neutral, dust, etc.); or physical samples (chemical, biological, etc.). Sensor systems typically do not require an observatory.

In general, only TABS 8.1.3 Optical Components and TABS 8.2.1 Large Mirror Systems require the development of optical manufacturing the testing technology.

\subsubsection{Remote Sensing Instruments/Sensors Technologies}

Remote Sensing Instruments/Sensors include: components, sensors, and instruments that manipulate and convert E\&M radiation (photons or waves) into science data; components and systems that generate E\&M radiation (photons or waves); and support technologies such as electronics and cryogenic/thermal sub-systems. Science Instruments typically require an observatory. They may be stand-alone sharing a common spacecraft bus with other Science Instruments or Sensor Systems (each with its own dedicated observatory subsystem as is the case of many Earth science or planetary missions). Or, they may be integrated with a single observatory (as is the case of many astrophysics missions). 
Major science instrument challenges include:

- Detectors/Focal Planes: Improve sensitivity and operating temp. of single-element and large-array devices;

- Electronics: Radiation-hardened electronics with reduced volume, mass and power;

- Optics: High-throughput optics with large fields of view, high stability, spectral resolution, and uniformity at many different temperatures;

- Microwave/Radio Transmitters and Receivers: Low-noise amplifier technologies, with reliable low-power high-speed digital- and mixed-signal processing electronics and algorithms;

- Lasers: Reliable, highly stable, efficient, radiation hardened, and long lifetime ( $>5$ years); and

- Cryogenic/Thermal Systems: Low power, lightweight, and low exported vibration.

Science Instruments require both incremental improvements and breakthrough Optical Technologies to enable entirely new instrument or observatory architectures. Optical component technology challenges include: starlight suppression; active wavefront control; and advanced spectrometers/instruments. Specific needs include:

- Broadband and spectral optical coatings for uniform high throughput;

- Ability to fabricate aspheric optical components for novel optical systems with large fields of view;

- Highly stable optical support structures;

- High spectral resolution dispersive elements; and

- Precision Wavefront Sensing and Control.

Table 2 details the Optical Component technology needed to enable new Remote Sensing Instruments and Sensors. It defines the Technology Metric required to enable the capability, the metric's current State of the Art and its Needed performance. The next two columns indicate when technology development needs to start and when the capability needs to achieve TRL-6. The last column gives the driving mission needing the capability. There are a wide variety of instrument types optimized for each science need and only some of the most critical technologies are described.

\begin{tabular}{|c|c|c|c|c|c|c|}
\hline \multicolumn{7}{|c|}{ Table 2: Science instruments Technology Challenges } \\
\hline & Technology Metric & State of Art & Need & Start & TRL6 & Mission \\
\hline \multirow{17}{*}{ 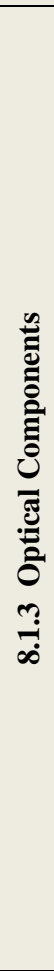 } & \multicolumn{6}{|l|}{ 8.1.3.1 Starlight Suppression } \\
\hline & Coronagraph or occulter & $\begin{array}{l}\text { Contrast Vis }>1 \times 10^{-9} \\
\text { Contrast mid-IR } 1 \times 10^{-5}\end{array}$ & $\begin{array}{l}<1 \times 10^{-10} \\
<1 \times 10^{-7} \\
1 \times 10^{-11} / \text { image } \\
20 \% \text {, at } V, I,\end{array}$ & $\begin{array}{l}2011 \\
2011\end{array}$ & $\begin{array}{l}2016 \\
2011\end{array}$ & Astro \\
\hline & Starlight suppression & $\begin{array}{l}\text { Bandwidth: } \\
\text { Passband: Partial }\end{array}$ & $\begin{array}{l}3 \mathrm{ksec} \\
\text { Broad }\end{array}$ & 2011 & 2020 & Astro \\
\hline & \multicolumn{6}{|c|}{ 8.1.3.2 Active Wavefront Control } \\
\hline & Wavefront control & $20 \mathrm{~nm}$ & $1-5 \mathrm{~nm}$ & 2011 & 2020 & Astro \\
\hline & Wavefront sensing & $10 \mathrm{~nm}$ & $1-5 \mathrm{~nm}$ & 2011 & 2020 & Astro \\
\hline & Bandwidth & Varies & $1 \mathrm{hz}, 1-5 \mathrm{~nm}$ & 2011 & 2020 & Astro \\
\hline & \multicolumn{6}{|l|}{ 8.1.3.3 Optical Components } \\
\hline & X-ray optics & 1 as lens/15as mirror & $.1 / 7 \operatorname{arcsec}$ & 2011 & 2014 & Helio \\
\hline & Instrument optics & $\begin{array}{l}\text { Transmission: } 90 \% \\
\text { Uniformity: } 80 \% \\
\text { Specific } \lambda \text { coating }\end{array}$ & $\begin{array}{l}\mathrm{T}>97 \% \\
\mathrm{U}>90 \% \\
\lambda 1-15 \mu \mathrm{m}\end{array}$ & 2010 & 2020 & Planet \\
\hline & Filters/coatings & $\begin{array}{l}\text { Temp range, bandpass, } \\
\text { Trans reflectivity }\end{array}$ & High res, cryo & 2011 & 2020 & Many \\
\hline & Reflective filters & $5 \mathrm{~nm}$ FWHM, $80 \% \mathrm{R}$ & $2 \mathrm{~nm}$ FWHM, $>90 \% \mathrm{R}$ & 2011 & 2014 & Helio \\
\hline & \multicolumn{6}{|c|}{ 8.1.3.4 Advanced Spectrometers/Instruments } \\
\hline & UV image slicer & $\begin{array}{l}5 \text { slices, }>300 \mathrm{~nm} \text { wavelength } \\
\text { range }\end{array}$ & 20 slices, $90 \mathrm{~nm} \mathrm{WR}$ & 2011 & 2014 & Helio \\
\hline & Advanced spectrometers & $\begin{array}{l}\text { Miniaturization } \\
5-10 \mathrm{~kg} \text { single func. }\end{array}$ & $1-3 \mathrm{~kg}$ multi-function & 2010 & 2020 & Planet \\
\hline & Spectroscopy components & Fabry Perot at $50 \mathrm{~K}$ & 50K IR, 100K resn. & 2011 & 2020 & Many \\
\hline & Wide FOV reflective imager & $20 \mathrm{deg}, 30 \mathrm{~cm}$ aperture & $30 \mathrm{deg},>60 \mathrm{~cm}$ & 2011 & 2016 & Helio \\
\hline
\end{tabular}




\subsubsection{Observatory Technologies}

Observatory technologies are necessary to design, manufacture, test, and operate space telescopes and antennas, which collect, concentrate and/or transmit photons. Observatory technologies enable or enhance large-aperture monolithic and/or segmented single apertures as well as structurally connected and/or free-flying sparse and interferometric apertures. Applications span the electromagnetic spectrum, from X-ray to UVOIR to radio-wave. Based on the needs of planned and potential future NASA missions, it is possible to define six specific enabling observatory technologies:

- Large-Mirror Systems: Grazing incidence

- Large-Mirror Systems: Normal incidence

- Large Structures and Antenna: Ultra-stable structures

- Large Structures and Antenna: Large-deployable/assembled structures

- Large Structures and Antenna: Control of large structures

- Distributed Aperture: Formation flying

For all applications, regardless of whether the incumbent system is $0.5 \mathrm{~m}$ or $5 \mathrm{~m}$, the fundamental driving need is largercollecting aperture with better performance at a lower cost per square meter. The technologies for achieving this performance capability are:

- Ability to manufacture and test large-mirror systems (normal and grazing incidence);

- Ability to deposit large-aperture, uniform (amplitude and polarization), broadband high reflectance coatings;

- Ability to structurally hold the mirror system in a stable, strain-free state under the influence of anticipated dynamic and thermal stimuli; and,

- Ability to create extra-large apertures via deployment, assembly, or formation flying — where formationflying technology is an actively controlled virtual structure.

One non-telescope application is the manufacture, deployment, in-plane and formation-flying control of an externalocculting star-shade to block starlight for exo-planet observation.

Similar optical technologies are needed to design, manufacture and test science instruments and telescopes. A good example is WFSC. While typically implemented inside a science instruments, WFSC provides feedback to operate and correct space telescopes. Another important technology is validated performance models that integrate optical, mechanical, dynamic, and thermal models for telescopes, structures, instruments, and spacecraft. This capability enables the design and manufacture of observatories whose performance requirements cannot be tested on the ground. Other technologies include new materials to enable ultra-stable large space structures; terabit communication; and autonomous rendezvous and docking for on-orbit assembly of very large structures.

Table 3 details technology needed to enable new Observatories. For each TABS, the table defines the Technology Metric required to enable the capability, the metric's current State of the Art and its Needed performance. The next two columns indicate when technology development needs to start and when the capability needs to achieve TRL-6. The last column gives the driving mission needing the capability. There are a wide variety of technologies to produce large aperture technologies and only some are described. These technologies support three primary applications: X-ray astronomy, UVOIR astronomy, and microwave/radiowave antenna.

Chandra, HERO, FOXSI, XMM, and the soon-to-be launched NuSTAR currently define the state of the art in X-ray astronomy. Pull requirements for X-ray astronomy are defined by IXO and FOXSI-3. Missions like Gen-X define X-ray 'push' requirements. Hubble, JWST, and commercial imaging systems, such as QuckBird, represent the state of the art in UVOIR. Pull requirements for UVOIR are defined by WFIRST, TPF-C, and ATLAST-8 or ATLAST-9. Missions like ATLAST-16 define push requirements for extremely large space telescopes (ELST) in the 15- to 30-m class range. GRIPS, ONEP, SWOT, ACE, and SCLP represent future pull requirements for antenna and booms. 


\begin{tabular}{|c|c|c|c|c|c|c|}
\hline \multicolumn{7}{|c|}{ Table 3: Observatory Technology Challenges } \\
\hline & Technology Metric & State of Art & Need & Start & TRL6 & Mission \\
\hline \multirow{8}{*}{ 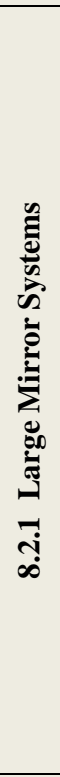 } & \multicolumn{6}{|l|}{ 8.2.1.1 Grazing Incidence } \\
\hline & 1 to $100 \mathrm{keV}$ FWHM resolution & $10 \operatorname{arcsec}$ & $<5 \operatorname{arcsec}$ & 2011 & 2014 & FOXSI-3 \\
\hline & $\begin{array}{l}\text { Aperture diameter } \\
\text { FWHM resolution } \\
\text { Areal density; Areal cost }\end{array}$ & \begin{tabular}{|l|}
$0.3 \mathrm{~m} 2$ \\
$15 \mathrm{arcsec}$ \\
$10 \mathrm{~kg} / \mathrm{m} 2$
\end{tabular} & $\begin{array}{l}>3 \mathrm{~m} 2 \\
<5 \operatorname{arcsec}\end{array}$ & 2011 & 2020 & IXO \\
\hline & $\begin{array}{l}\text { Aperture diameter } \\
\text { FWHM angular resolution } \\
\text { Areal density (depends on LV) } \\
\text { Active Control }\end{array}$ & $\begin{array}{l}0.3 \mathrm{~m} 2 \\
15 \mathrm{arcsec} \\
10 \mathrm{~kg} / \mathrm{m} 2 \\
\text { No }\end{array}$ & $\begin{array}{l}>50 \mathrm{~m} 2 \\
<1 \mathrm{arcsec} \\
1 \mathrm{~kg} / \mathrm{m} 2 \text { (depend LV) } \\
\text { Yes }\end{array}$ & 2011 & 2030 & $\begin{array}{l}\text { Push } \\
\text { GenX }\end{array}$ \\
\hline & \multicolumn{6}{|l|}{ 8.2.1.2 Normal Incidence } \\
\hline & $\begin{array}{l}\text { Size \& polarization } \\
\text { Areal density }\end{array}$ & \begin{tabular}{|l} 
Planck \\
$\sim 20 \mathrm{~kg} / \mathrm{m} 2$
\end{tabular} & $\begin{array}{l}1.6 \mathrm{~m} \\
<6 \mathrm{~kg} / \mathrm{m} 2\end{array}$ & \begin{tabular}{|l|}
2011 \\
2018
\end{tabular} & $\begin{array}{l}2020 \\
2024\end{array}$ & \begin{tabular}{|l} 
ITP \\
3DWinds
\end{tabular} \\
\hline & $\begin{array}{l}\text { Aperture diameter } \\
\text { Figure } \\
\text { Stability (dynamic \& thermal) } \\
\text { Reflectivity } \\
\text { Areal density (depends on LV) } \\
\text { Areal cost }\end{array}$ & $\begin{array}{l}2.4 \mathrm{~m} \\
<10 \mathrm{~nm} \mathrm{rms} \\
--- \\
>60 \%, 120-900 \mathrm{~nm} \\
240 \mathrm{~kg} / \mathrm{m} 2 \\
\$ 12 \mathrm{M} / \mathrm{m} 2\end{array}$ & $\begin{array}{l}3 \text { to } 8 \mathrm{~m} \\
<10 \mathrm{~nm} \mathrm{rms} \\
>9,000 \mathrm{~min} \\
>60 \%, 90-900 \mathrm{~nm} \\
20(\text { or } 400) \mathrm{kg} / \mathrm{m} 2 \\
<\$ 2 \mathrm{M} / \mathrm{m} 2\end{array}$ & 2011 & 2020 & $\begin{array}{l}\text { NWTP } \\
\text { UVOTP }\end{array}$ \\
\hline & $\begin{array}{l}\text { Aperture diameter } \\
\text { Areal density (depends on LV) } \\
\text { Areal cost }\end{array}$ & $\begin{array}{l}6.5 \mathrm{~m} \\
50 \mathrm{~kg} / \mathrm{m} 2 \\
\$ 6 \mathrm{M} / \mathrm{m} 2\end{array}$ & $\begin{array}{l}15 \text { to } 30 \mathrm{~m} \\
5(\text { or } 100) \mathrm{kg} / \mathrm{m} 2 \\
<\$ 0.5 \mathrm{M} / \mathrm{m} 2\end{array}$ & & 2030 & $\begin{array}{l}\text { Push } \\
\text { EL-ST }\end{array}$ \\
\hline \multirow{12}{*}{ 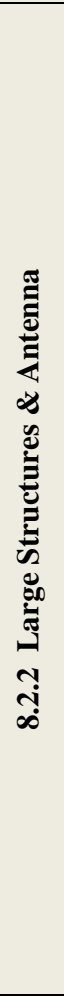 } & \multicolumn{6}{|c|}{ 8.2.2.1 Passive Ultra-Stable Structures } \\
\hline & Thermal stability & Chandra & WFOV PSF Stability & 2011 & 2014 & WFIRST \\
\hline & $\begin{array}{l}\text { Aperture diameter } \\
\text { Thermal/dynamic stability } \\
\text { Line-of-sight jitter WFE } \\
\text { Areal density (depends on LV) } \\
\text { Areal cost }\end{array}$ & \begin{tabular}{|l|}
$6.5 \mathrm{~m}$ \\
$60 \mathrm{~nm} \mathrm{rms}$ \\
$1.6 \mathrm{mas}$ \\
$40 \mathrm{~kg} / \mathrm{m} 2$ \\
$\$ 4 \mathrm{M} / \mathrm{m} 2$ \\
\end{tabular} & $\begin{array}{l}8 \mathrm{~m} \\
15 \mathrm{~nm} \text { rms } \\
1 \mathrm{mas} \\
<20(\text { or } 400) \mathrm{kg} / \mathrm{m} 2 \\
<\$ 2 \mathrm{M} / \mathrm{m} 2 \\
\end{array}$ & 2011 & 2020 & NW/UVO \\
\hline & \multicolumn{6}{|c|}{ 8.2.2.2 Deployable/Assembled Telescope Support Structure and Antenna } \\
\hline & $\begin{array}{l}\text { Antenna aperture } \\
\text { Antenna aperture } \\
\text { Surface figure }\end{array}$ & $5 \mathrm{~m}$ & $\begin{array}{l}6 \mathrm{~m} \\
>10 \mathrm{~m} \\
<0.1 \mathrm{~mm} \mathrm{rms}\end{array}$ & $\begin{array}{l}2013 \\
2016\end{array}$ & $\begin{array}{l}2019 \\
2023\end{array}$ & $\begin{array}{l}\text { ACE } \\
\text { SCLP }\end{array}$ \\
\hline & $\begin{array}{l}\text { Boom length } \\
\text { Stiffness } \\
\text { Pointing stability }\end{array}$ & & $\begin{array}{l}\geq 20 \mathrm{~m} \\
10^{7} \mathrm{~N} \mathrm{~m}^{2} \\
0.005 \mathrm{arcsec} \operatorname{roll} / 3 \mathrm{~min}\end{array}$ & 2011 & 2014 & $\begin{array}{l}\text { GRIPS } \\
\text { ONEP } \\
\text { SWOT }\end{array}$ \\
\hline & Occulter diameter & Few cm & 30 to $100 \mathrm{~m}$ & 2011 & 2020 & NWTP \\
\hline & Aperture diameter & $6.5 \mathrm{~m}$ & $8 \mathrm{~m}$ & 2011 & 2020 & NW/UVO \\
\hline & Aperture diameter & $6.5 \mathrm{~m}$ & 15 to $30 \mathrm{~m}$ & & 2030 & EL-ST \\
\hline & \multicolumn{6}{|l|}{ 8.2.2.3 Active Control } \\
\hline & $\begin{array}{l}\text { Occulter pedal control } \\
\text { Occulter modal control } \\
\text { Boom tip control }\end{array}$ & & $\begin{array}{l}<0.5 \mathrm{deg} \\
<0.1 \mathrm{~mm} \mathrm{rms} \\
\sim 0.5 \mathrm{deg}\end{array}$ & $\begin{array}{l}2011 \\
2012\end{array}$ & $\begin{array}{l}2020 \\
2014\end{array}$ & $\begin{array}{l}\text { NWTP } \\
\text { GRIPS }\end{array}$ \\
\hline & $\begin{array}{l}\text { Aperture diameter } \\
\text { Aperture diameter } \\
\text { Thermal/dynamic stability } \\
\text { Line-of-Sight jitter WFE } \\
\text { Areal density (depends on LV) } \\
\text { Areal cost }\end{array}$ & \begin{tabular}{|l|}
$6.5 \mathrm{~m}$ \\
$6.5 \mathrm{~m}$ \\
$60 \mathrm{~nm} \mathrm{rms}$ \\
$1.6 \mathrm{mas}$ \\
$40 \mathrm{~kg} / \mathrm{m} 2$ \\
$\$ 4 \mathrm{M} / \mathrm{m} 2$ \\
\end{tabular} & $\begin{array}{l}8 \mathrm{~m} \\
15 \text { to } 30 \mathrm{~m} \\
15 \mathrm{~nm} \text { rms } \\
1 \mathrm{mas} \\
<20(\text { or } 400) \mathrm{kg} / \mathrm{m} 2 \\
<\$ 2 \mathrm{M} / \mathrm{m} 2\end{array}$ & 2011 & $\begin{array}{l}2020 \\
2030\end{array}$ & $\begin{array}{l}\text { NW/UVO } \\
\text { Push } \\
\text { EL-ST }\end{array}$ \\
\hline \multirow{3}{*}{ 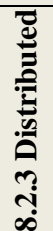 } & \multicolumn{6}{|l|}{ 8.2.3.1 Formation Flying } \\
\hline & Range & & 10,000 to $80,000 \mathrm{~km}$ & 2013 & 2016 & LISA \\
\hline & $\begin{array}{l}\text { Separation control } \\
\text { Lateral alignment } \\
\text { Relative position } \\
\text { Relative pointing }\end{array}$ & $\begin{array}{l}2 \mathrm{~m} \\
5 \mathrm{~cm} \mathrm{rms} \\
6.7 \text { arcmin } \mathrm{rms}\end{array}$ & $\begin{array}{l}100 \text { to } 400 \pm 0.1 \mathrm{~m} \\
\pm 0.7 \mathrm{~m} \text { wrt LOS } \\
<1 \mathrm{~cm} \mathrm{rms} \\
<1 \pm 0.1 \text { arcsec }\end{array}$ & 2011 & $\begin{array}{l}2015 \\
2024 \\
2030\end{array}$ & $\begin{array}{l}\text { ONEP } \\
\text { Occulter } \\
\text { NWTP } \\
\text { Push }\end{array}$ \\
\hline
\end{tabular}




\subsection{Technology Development Roadmap}

Technology Development Roadmaps were developed for each TABS area. Figure 2 shows the Observatory Technology Roadmap. The top rows contain missions currently identified in NASA planning documents and their potential launch dates. Only Astrophysics, Earth Science and Heliophysics missions have identified Observatory technology needs. The top rows also explicitly include the 2020 and 2030 NRC Decadal Reviews. The next rows correspond directly to the Technology Area Breakdown Structure of Figure 1 and 3. Horizontal solid blue lines indicate individual technology area funding durations. Triangles represent major milestones and diamonds represent decision points.

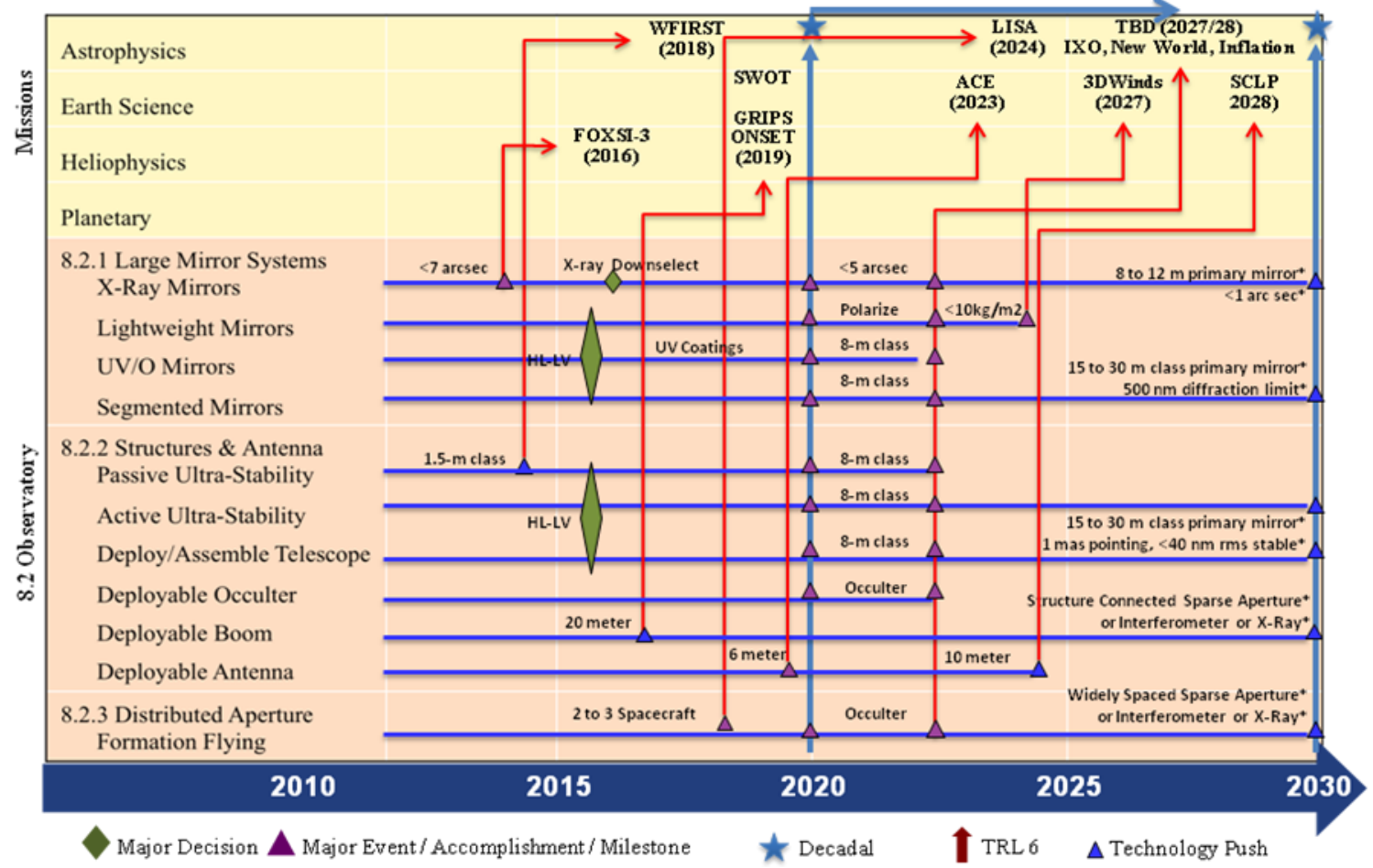

Figure 2: Observatory Technology Development Roadmap

Triangles represent milestones when technology maturity is required to make a decision. The triangles at 2020 are required for the Decadal review process. Triangles connected via solid vertical red lines indicate the date when all the technologies required for a given mission must achieve TRL-6 in order for that mission to move from development and into implementation. In the case of the TBD (2027/28) missions, which one actually 'flies' will depend on technology readiness and compelling science as determined via the Decadal process. While Explorer missions depend on technology development, it is not possible to identify a specific technology area with a specific Explorer mission. Explorer missions are selected via completion between concepts whose technologies are already at TRL-6 or higher.

Diamonds indicate decision points. There are three decision points in the Observatory roadmap. First, in preparation for the Decadal 2020 process, the X-Ray community needs to make a down select decision between competing $\mathrm{X}$-ray mirror technologies for a potential IXO mission and continue development of that approach towards TRL-6. Second, if NASA actually deploys a HLLV, it will have fundamental impacts on how future large aperture space telescopes are designed, fabricated and deployed. Until the availability and capacities of a potential future HLLV becomes known, it is necessary to fund parallel technology paths, i.e. how to launch large space telescopes with current EELVs; or how to launch large space telescopes with a HLLV. Once the status of HLLV is definitively known, then the prioritization of these two paths can be reassessed. 


\subsection{Summary of Top Technology Challenges}

The SIOSS roadmap identified a list of the most important near-, mid- and long-term technical challenges that would enhance or enable a wide range of potential science missions. Investment in technology maturation must be balanced between shorter- and longer-term needs, as many of the 2017-2022 and beyond technologies can take longer to develop. For each area, the goal is to advance the state of the art in the Technology Categories by at least $2 X$ to 10X and, in the case of long-term needs, to develop entirely new revolutionary capabilities. The Top Challenges which most effect optical manufacturing and testing are given in Table 4.

\begin{tabular}{|c|}
\hline Present to 2016 (Near Term) \\
\hline $\begin{array}{l}\text { Low-Cost, Large-Aperture Precision Mirrors } \\
\text { UV and optical lightweight mirrors, } 5 \text { to } 10 \mathrm{~nm} \mathrm{rms},<\$ 2 \mathrm{M} / \mathrm{m} 2,<30 \mathrm{~kg} / \mathrm{m} 2 \\
\text { X-ray: }<5 \text { arc second resolution, }<\$ 0.1 \mathrm{M} / \mathrm{m} 2 \text { (surface normal space) },<3 \mathrm{~kg} / \mathrm{m} 2\end{array}$ \\
\hline 2017 to 2022 (Mid Term) \\
\hline $\begin{array}{l}\text { High-Contrast Exoplanet Technologies } \\
\text { High-contrast nulling and coronagraphy }\left(1 \times 10^{\wedge}-10 \text {, broadband); occulters ( } 30 \text { to } 100 \text { meters, }<0.1 \mathrm{~mm} \mathrm{rms}\right)\end{array}$ \\
\hline $\begin{array}{l}\text { Ultra-Stable Large Aperture UV/O Telescopes } \\
\quad>50 \mathrm{~m} 2 \text { aperture, }<10 \mathrm{~nm} \text { rms surface, }<1 \text { mas pointing, }<15 \mathrm{~nm} \mathrm{rms} \text { stability, }<\$ 2 \mathrm{M} / \mathrm{m} 2\end{array}$ \\
\hline 2023 and Beyond (Long Term) \\
\hline $\begin{array}{l}\text { Advanced Spatial Interferometric Imaging } \\
\text { Wide field imaging \& nulling to spectroscopically image an Earth-twin with }>32 \times 32 \text { pixels at } 20 \text { parsecs. }\end{array}$ \\
\hline $\begin{array}{l}\text { Many Spacecraft in Formation } \\
\text { Alignment \& positioning of } 20 \text { to } 50 \text { spacecraft distributed over } 10 \text { s (to } 1000 \text { s) of kilometers to nanometer precision with } \\
\text { milli-arc second pointing knowledge and stability }\end{array}$ \\
\hline
\end{tabular}

\section{NRC PUBLIC COMMENTS ON SIOSS}

The initial NASA Technology Assessment Roadmaps were delivered to the National Research Council (NRC) in October 2010 who made them available for public review. During the winter and spring of 2012, the NRC solicited public comments. The Science Instrument, Observatory and Sensor Systems Technology Assessment received 63 inputs. Most of these inputs were corrections, clarifications and amplifications of content already in the report. Others pointed out technologies which the assessment team had missed entirely, such as technology needs for Gamma Ray science. Many of the inputs were made on behalf of individual science communities. Of the 63 inputs, 9 each related to Optical Component and Observatory Technology (18/63 or 28\%):

Optical Components received 2 inputs regarding wavefront sensing and control to correct phase, intensity, amplitude and polarization variations; 4 inputs for specific components ranging from $\mathrm{x}$-ray \& UV diffraction gratings to narrow band spectral filters to electronically steerable laser beam; 3 inputs microwave polarization feed horns and planar antenna.

Observatory received inputs for $8 \mathrm{~m}$ UVOIR and 4m UVOIR telescopes, 100 meter microwave antenna, high reflectance UV coatings, x-ray and gamma ray imaging optics on 20 meter booms, athermal telescope structures, $400 \mathrm{sq}$ meter microwave phased array antenna structure, 300 meter booms for atom interferometers and distributed aperture systems. 


\section{CONCLUSIONS}

New and improved optical manufacturing the testing technology is critical to enabling NASA's future high priority missions. To prepare for those missions requires a roadmap of how to get from the current state of the art to where technology needs to be in 5, 10, 15 and 20 years. The Science Instrument, Observatory and Sensor System (SIOSS) roadmap assesses the current technology needs required to enable future NASA Science Missions Directorate missions and identifies specific areas where substantial enhancements in mission capabilities are needed. These areas include challenges which require the maturation of optical manufacturing and testing technology. The Roadmap also provides strategic guidance for the agency's budget formulation and prioritization process.

The SIOSS Team employed a multi-step process. The first step performed an SMD needs assessment. The second step consolidated the identified technology needs into broad categories and organized them into a Technology Area Breakdown Structure (TABS). The next step generated technology development roadmaps for each TABS element. For each technology area, the state of the art was detailed and both 'push' and 'pull' technology needs identified. Pull technologies enable or enhance capabilities required by future planned NASA missions. Push technologies enable previously unachievable mission requirements or solved long-term strategic challenges.

An initial report was presented to the NRC in Oct 2010 (http://www.nasa.gov/offices/oct/home/roadmaps/index.html). And, the NRC review report is expected in late summer 2011.

\section{REFERENCES}

1. Stahl, et. al., "Summary of the NASA Science Instrument, Observatory and Sensor System (SIOSS) Technology Assessment", SPIE Proceedings UVOIR Space Telescope and Instruments, 2011

\section{BIBLOGRAPHY}

SIOSS technology needs and challenges are traceable to either specific NASA science missions planned by the Science Mission Directorate ('pull technology') or emerging measurement techniques necessary to enable new scientific discovery ('push technology'). A variety of top-level strategic documents and planning documents that articulate NASA and research community priority objectives were used to prepare the SIOSS roadmaps:

2010 Science Plan, NASA Science Mission Directorate, 2010

Agency Mission Planning Manifest, 2010

New Worlds, New Horizons in Astronomy and Astrophysics, NRC Decadal Survey, 2010

Panel Reports - New Worlds, New Horizons in Astronomy and Astrophysics, NRC Decadal Survey, 2010

Heliophysics, The Solar and Space Physics of a New ERA, Heliophysics Roadmap Team Report to the NASA Advisory Council, 2009

Launching Science: Science Opportunities provided by NASA's Constellation System, report of National Research Council's Space Studies Board, National Academy Press, 2008

Earth Science and Applications from Space, NRC Decadal Survey, 2007

New Frontiers in the Solar Systems, NRC Planetary Decadal Survey, 2003

The Sun to the Earth - and Beyond, NRC Heliophysics Decadal Survey, 2003

Advanced Telescopes and Observatories, APIO, 2005

Science Instruments and Sensors Capability, APIO, 2005 


\section{Optical manufacturing and testing requirements identified by the NASA Science Instruments, Observatories and Sensor Systems Technology Assessment}

H. Philip Stahl, NASA Marshall Space Flight Center

Rich Barney, NASA Goddard Space Flight Center

Jill Bauman, NASA Ames Research Center

Lee Feinberg, NASA Goddard Space Flight Center

Dan Mccleese, Jet Propulsion Laboratory

Upendra Singh, NASA Langley Research Center 


\section{AGENDA}

Office of Chief Technologist (OCT) Technology Area Roadmap

Science Instrument, Observatory and Sensor Systems TA

Needs Assessment

Technology Area Breakdown Structure (TABS)

Technology Development Roadmaps

Top Challenges

Interdependencies with other TAs and Government Agencies

Budget Recommendations

Conclusions 
NASA Office of Chief Technologist

Aero-Space Technology Area Roadmap

(A-STAR) 


\section{Aero-Space Technology Area Roadmap (A-STAR)}

July 2010, NASA Office of Chief Technologist (OCT) initiated an activity to create and maintain a NASA integrated roadmap for 15 key technology areas which recommend an overall technology investment strategy and prioritize NASA's technology programs to meet NASA's strategic goals.

Initial reports were presented to the National Research Council who are currently collecting public input and preparing reviews of each Roadmap.

Roadmaps will be updated annually and externally reviewed every 4 years consistent with the Agency's Strategic Plans. 


\section{A-STAR Process}

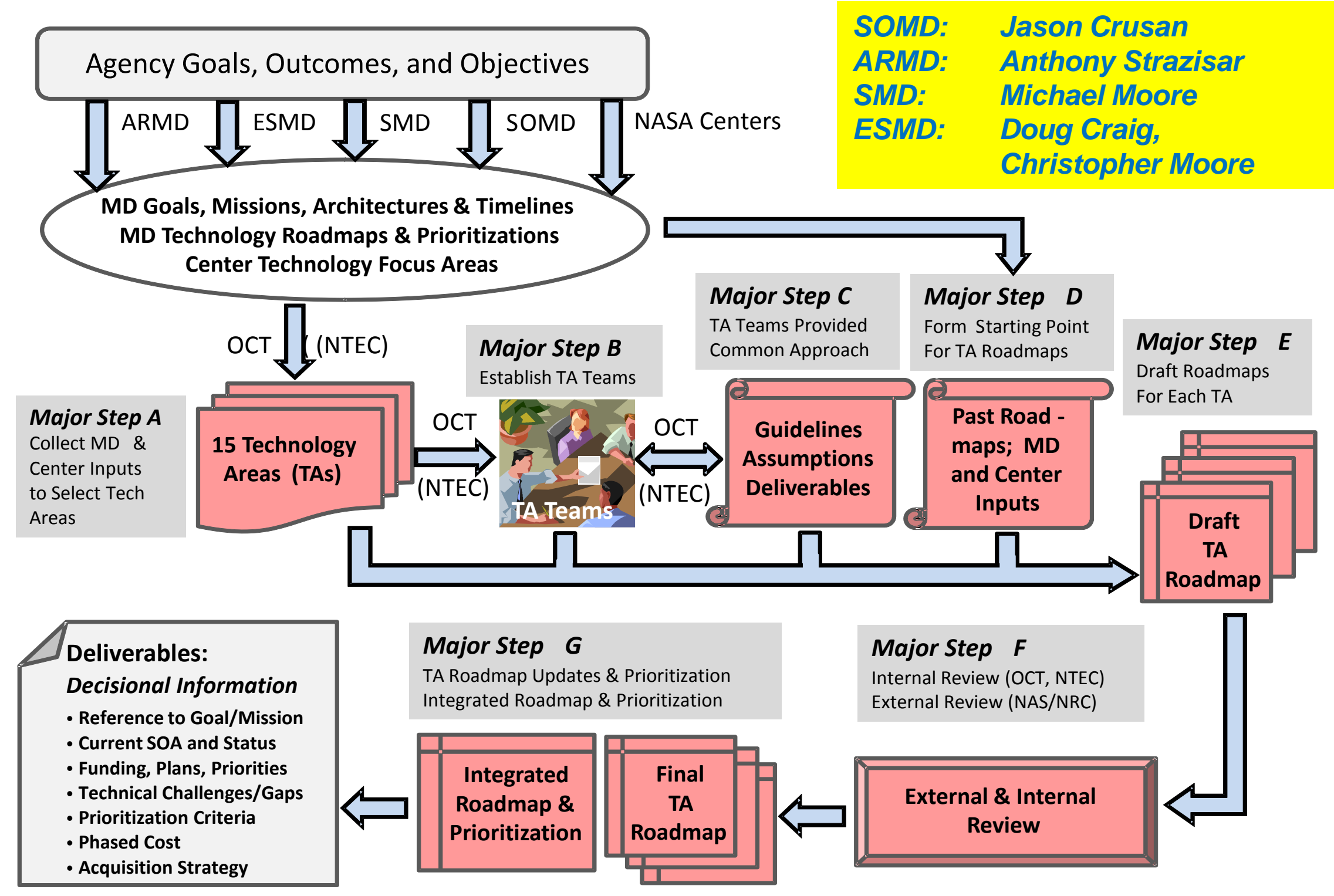




\section{Technology Assessment Areas}

TA1: Launch Propulsion Systems

TA2: In-Space Propulsion Systems

TA3: $\quad$ Space Power and Energy Storage Systems

TA4: Robotics, Tele-robotics, and Autonomous Systems

TA5: Communication and Navigation Systems

TA6: Human Health, Life Support and Habitation Systems

TA7: Human Exploration Destination Systems

TA8: Scientific Instruments, Observatories, and Sensor Systems

TA9: Entry, Descent, and Landing Systems

TA10: Nanotechnology

TA11: Modeling, Simulation, Information Technology, and Processing

TA12: Materials, Structural \& Mechanical Systems, and Manufacturing

TA13: Ground and Launch Systems Processing

TA14: Thermal Management Systems

TA15: Aeronautics 


\section{Goals and Benefits}

Develop clear NASA technology portfolio recommendations

Prioritize current needs

Define development plans

Identify alternative paths

Reveal interrelationships of between various technologies

Transparency in government technology investments

Ensure needs of all NASA Mission Directorates are included

Credibility for planned NASA technology programs

Coordinate with other Government agencies

Broad-based input from non-government parties 


\section{Charge to TA Teams}

Review, document, and organize the existing roadmaps and technology portfolios.

Collect input from key Center subject matter experts, program offices and Mission Directorates.

Take into account:

US aeronautics and space policy;

NASA Mission Directorate strategic goals and plans;

Existing Design Reference Missions, architectures and timelines; and Past NASA technology and capability roadmaps.

Recommend 10-yr Budget to Mature Technology to TRL6 


\section{Technology Assessment Content}

Define a breakdown structure that organizes and identifies the TA Identify and organize all systems/technologies involved in the TA using a 20-year horizon

Describe the state-of-the-art (SOA) for each system

Identify the various paths to achieve performance goals

Identify NASA planned level of investment Assess gaps and overlaps across planned activities

Identify alternate technology pathways

Identify key challenges required to achieve goals 


\section{Technology Assessment \#8:}

Science Instruments, Observatories and Sensor Systems

(SIOSS) 


\section{TA8 Roadmap Team}

Rich Barney (GSFC), Division Chief, Instrument Systems and Technology Division. Co-chaired 2005 NASA Science Instruments and Sensors Capability Roadmap.

Phil Stahl (MSFC), Senior Optical Physicists

Optical Components Technical Lead for James Webb Space Telescope;

Mirror Technology Days in the Government;

Advanced Optical Systems SBIR Subtopic Manager;

2005 Advanced Observatories and Telescopes Capability Roadmap.

Upendra Singh (LaRC), Chief Technologist, Engineering Directorate.

Principal Investigator for NASA Laser Risk Reduction Program (2002-2010)

Dan Mccleese (JPL), Chief Scientist

Principal Investigator of Mars Climate Sounder instrument on Mars Reconnaissance Orbiter.

Jill Bauman (ARC), Associate Director of Science for Mission Concepts.

Lee Feinberg (GSFC), Chief Large Optics System Engineer

JWST OTE Manager.

Co-chaired 2005Advanced Telescopes and Observatories Capability Roadmap. 


\section{SIOSS}

SIOSS roadmap addresses technology needs to achieve NASA's highest priority objectives - not only for the Science Mission Directorate (SMD), but for all of NASA.

SIOSS Team employed a multi-step process.

- Performed an SMD needs assessment;

- Consolidated the identified technology needs into broad categories and organized them into a Technology Area Breakdown Structure (TABS);

- Generated technology development roadmaps for each TABS element;

- Investigated interdependencies with other TA Areas as well as the needs of Other Government Agencies. 


\section{SMD Needs Assessment}

First step was to review governing documents (such as Decadal Surveys, roadmaps, and science plans) for each Science Mission Directorate (SMD) divisions: Astrophysics, Earth Science, Heliophysics, and Planetary Science:

2010 Science Plan, NASA Science Mission Directorate, 2010

Agency Mission Planning Manifest, 2010

New Worlds, New Horizons in Astronomy and Astrophysics, NRC Decadal Survey, 2010

Panel Reports: - New Worlds, New Horizons in Astronomy and Astrophysics, NRC Decadal

Survey, 2010

Heliophysics, The Solar and Space Physics of a New ERA, Heliophysics Roadmap Team

Report to the NASA Advisory Council, 2009

Earth Science and Applications from Space, NRC Decadal Survey, 2007

New Frontiers in the Solar Systems, NRC Planetary Decadal Survey, 2003

The Sun to the Earth - and Beyond, NRC Heliophysics Decadal Survey, 2003

Advanced Telescopes and Observatories, APIO, 2005

Science Instruments and Sensors Capability, APIO, 2005 


\section{Astrophysics Technology Needs}

National Academy 2010 Decadal Report recommended missions and technology-development programs, (with need date):

Wide Field Infrared Survey Telescope (WFIRST), 2018

Explorer Program, 2019/2023

Laser Interferometer Space Antenna (LISA), 2024

International X-ray Observatory (IXO), mid/late 2020s

New Worlds Technology Development Program, mid/late 2020s

Epoch of Inflation Technology Development Program, mid/late 2020s

U.S. Contribution to the JAXA-ESA SPICA Mission, 2017

UV-Optical Space Capability Technology Development Program, mid/late 2020s

TRL3-to-5 Intermediate Technology Development Program

All can be enhanced or enabled by technology development to reduce cost, schedule, and performance risks. 


\section{SMD Needs Assessment}

Detailed listings of technology needs for each SMD division were tabulated which enable either:

planned SMD missions ('pull technology') or

emerging measurement techniques necessary for new scientific discovery

('push technology').

These lists were then reviewed and refined by individual mission and technology-development stakeholders. 
Table 2.2.1.1 - 1 Summary of Astrophysics Technology Needs

\begin{tabular}{|c|c|c|c|c|c|c|}
\hline Mission & Technology & Metric & State of Art & Need & Start & TRL6 \\
\hline WFIRST & NIR detectors & $\begin{array}{l}\text { Pixel array } \\
\text { Pixel size }\end{array}$ & $\begin{array}{l}2 \mathrm{k} \times 2 \mathrm{k} \\
18 \mu \mathrm{m}\end{array}$ & $\begin{array}{l}4 \mathrm{k} \mathrm{x} 4 \mathrm{k} \\
10 \mu \mathrm{m}\end{array}$ & 2012 & 2014 \\
\hline $\begin{array}{l}\text { UVOTP } \\
\text { Push }\end{array}$ & $\begin{array}{l}\text { Detector arrays: } \\
\text { Low noise }\end{array}$ & $\begin{array}{l}\text { Pixel } \\
\text { QE UV } \\
\text { QE Visible } \\
\text { Rad Hard } \\
\end{array}$ & $2 \mathrm{k} \times 2 \mathrm{k}$ & $\begin{array}{l}4 \mathrm{k} \mathrm{x} 4 \mathrm{k} \\
>0.590-300 \mathrm{~nm} \\
>0.8300-900 \mathrm{~nm} \\
50 \text { to } 200 \mathrm{kRad}\end{array}$ & 2012 & 2020 \\
\hline $\begin{array}{l}\text { NWTP } \\
\text { Push }\end{array}$ & Photon counting arrays & $\begin{array}{l}\text { Pixel array visible } \\
\text { Visible QE } \\
\text { Pixel array NIR }\end{array}$ & $\begin{array}{l}512 \times 512 \\
80 \% 450-750 \mathrm{~nm} \\
128 \times 128\end{array}$ & $\begin{array}{l}1 \mathrm{k} \times 1 \mathrm{k} \\
>80 \% 450-900 \mathrm{~nm} \\
256 \times 256\end{array}$ & 2011 & 2020 \\
\hline $\begin{array}{l}\text { SPICA } \\
\text { ITP } \\
\text { Push }\end{array}$ & Far-IR detector arrays & $\begin{array}{l}\text { Sens. (NEP W/ } / \sqrt{H z} \text { ) } \\
\text { Wavelength } \\
\text { Pixels }\end{array}$ & $\begin{array}{l}1 \mathrm{e}-18 \\
>250 \mu \mathrm{m} \\
256\end{array}$ & $\begin{array}{l}3 \mathrm{e}-20 \\
35-430 \mu \mathrm{m} \\
1 \mathrm{k} \times 1 \mathrm{k}\end{array}$ & 2011 & $\begin{array}{l}2015 \\
2020\end{array}$ \\
\hline $\begin{array}{l}\text { IXO } \\
\text { Push }\end{array}$ & X-ray detectors & $\begin{array}{l}\text { Pixel array } \\
\text { Noise } \\
\text { QE } \\
\text { Frame rate }\end{array}$ & $\begin{array}{l}10-15 \mathrm{e}^{-} \mathrm{RMS} \\
100 \mathrm{kHz} @ 2 \mathrm{e}^{-}\end{array}$ & $\begin{array}{l}40 \text { x } 40 \text { TES } \\
2-4 \mathrm{e}^{-} \mathrm{RMS} \\
>0.70 .3-8 \mathrm{keV} \\
0.5-1 \mathrm{MHz} @ 2 \mathrm{e}^{-}\end{array}$ & 2011 & 2015 \\
\hline $\begin{array}{l}\text { WFIRST } \\
\text { IXO }\end{array}$ & Detector ASIC & $\begin{array}{l}\text { Speed @ low noise } \\
\text { Rad tolerance }\end{array}$ & $\begin{array}{l}100 \mathrm{kHz} \\
14 \mathrm{krad}\end{array}$ & $\begin{array}{l}0.5-1 \mathrm{MHz} \\
55 \mathrm{krad}\end{array}$ & 2011 & 2013 \\
\hline NWTP & $\begin{array}{l}\text { Visible Starlight } \\
\text { suppression: } \\
\text { coronagraph or } \\
\text { occulter }\end{array}$ & $\begin{array}{l}\text { Contrast } \\
\text { Contrast stability } \\
\text { Passband } \\
\text { Inner Working Angle }\end{array}$ & $\begin{array}{l}>1 \times 10^{-9} \\
--- \\
10 \%, 760-840 \mathrm{~nm} \\
4 \lambda / \mathrm{D}\end{array}$ & $\begin{array}{l}<1 \times 10^{-10} \\
1 \times 10^{-11} / \text { image } \\
20 \%, \text { at } V, I, \text { and } R \\
2 \lambda / \mathrm{D}-3 \lambda / \mathrm{D}\end{array}$ & $\begin{array}{l}2011 \\
2011\end{array}$ & $\begin{array}{l}2016 \\
2020\end{array}$ \\
\hline NWTP & $\begin{array}{l}\text { Mid-IR Starlight } \\
\text { suppres: interferometer }\end{array}$ & $\begin{array}{l}\text { Contrast } \\
\text { Passband mid-IR }\end{array}$ & $\begin{array}{l}1.65 \times 10^{-5}, \text { laser } \\
30 \% \text { at } 10 \mu \mathrm{m}\end{array}$ & $\begin{array}{l}<1 \times 10^{-7} \text {, broadband } \\
>50 \% 8 \mu \mathrm{m}\end{array}$ & $\begin{array}{l}2011 \\
2011\end{array}$ & $\begin{array}{l}2016 \\
2020\end{array}$ \\
\hline $\begin{array}{l}\text { NWTP } \\
\text { UVOTP }\end{array}$ & $\begin{array}{l}\text { Active WFSC; } \\
\text { Deformable Mirrors }\end{array}$ & $\begin{array}{l}\text { Sensing } \\
\text { Control (Actuators) }\end{array}$ & $\begin{array}{l}\lambda / 10,000 \mathrm{rms} \\
32 \times 32\end{array}$ & $\begin{array}{l}<\lambda / 10,000 \mathrm{rms} \\
128 \times 128\end{array}$ & 2011 & 2020 \\
\hline IXO & XGS CAT grating & Facet size; Throughput & $3 \times 3 \mathrm{~mm} ; 5 \%$ & $60 \times 60 \mathrm{~mm} ; 45 \%$ & 2010 & 2014 \\
\hline Various & Filters \& coatings & Reflect/transmit; temp & & & 2011 & 2020 \\
\hline Various & Spectroscopy & Spectral range/resolve & & & 2011 & 2020 \\
\hline $\begin{array}{l}\text { SPICA } \\
\text { IXO }\end{array}$ & $\begin{array}{l}\text { Continuous sub-K } \\
\text { refrigerator }\end{array}$ & $\begin{array}{l}\text { Heat lift } \\
\text { Duty cycle }\end{array}$ & $\begin{array}{l}<1 \mu \mathrm{W} \\
90 \%\end{array}$ & $\begin{array}{l}>1 \mu \mathrm{W} \\
100 \%\end{array}$ & 2011 & 2015 \\
\hline $\begin{array}{l}\text { IXO } \\
\text { Push }\end{array}$ & $\begin{array}{l}\text { Large X-ray mirror } \\
\text { systems }\end{array}$ & $\begin{array}{l}\text { Effective Area } \\
\text { HPD Resolution } \\
\text { Areal Density; Active }\end{array}$ & $\begin{array}{l}0.3 \mathrm{~m} 2 \\
15 \operatorname{arcsec} \\
10 \mathrm{~kg} / \mathrm{m} 2 ; \text { no }\end{array}$ & $\begin{array}{l}>3 \mathrm{~m} 2(50 \mathrm{~m} 2) \\
<5 \operatorname{arcsec}(<1 \text { as }) \\
1 \mathrm{~kg} / \mathrm{m} 2 ; \text { yes }\end{array}$ & 2011 & $\begin{array}{c}2020 \\
(30)\end{array}$ \\
\hline $\begin{array}{l}\text { NWTP } \\
\text { UVOTP } \\
\text { Push }\end{array}$ & $\begin{array}{l}\text { Large UVOIR mirror } \\
\text { systems }\end{array}$ & $\begin{array}{l}\text { Aperture diameter } \\
\text { Figure } \\
\text { Stability } \\
\text { Reflectivity } \\
\mathrm{kg} / \mathrm{m} 2 \\
\$ / \mathrm{m} 2\end{array}$ & $\begin{array}{l}2.4 \mathrm{~m} \\
<10 \mathrm{~nm} \mathrm{rms} \\
--- \\
>60 \%, 120-900 \mathrm{~nm} \\
30 \mathrm{~kg} / \mathrm{m} 2 \\
\$ 12 \mathrm{M} / \mathrm{m} 2\end{array}$ & $\begin{array}{l}3 \text { to } 8 \mathrm{~m}(15 \text { to } 30 \mathrm{~m}) \\
<10 \mathrm{~nm} \mathrm{rms} \\
>9,000 \mathrm{~min} \\
>60 \%, 90-1100 \mathrm{~nm} \\
\text { Depends on } \mathrm{LV} \\
<\$ 1 \mathrm{M} / \mathrm{m} 2\end{array}$ & 2011 & $\begin{array}{c}2020 \\
(30)\end{array}$ \\
\hline WFIRST & Passive stable structure & Thermal stability & Chandra & WFOV PSF Stable & 2011 & 2014 \\
\hline NWTP & Large structure: occulter & Dia; Petal Edge Tol & Not demonstrated & $30-80 \mathrm{~m} ;<0.1 \mathrm{~mm} \mathrm{rms}$ & 2011 & 2016 \\
\hline $\begin{array}{l}\text { NWTP } \\
\text { UVOTP } \\
\text { Push }\end{array}$ & $\begin{array}{l}\text { Large, stable telescope } \\
\text { structures } \\
\text { (Passive or active) }\end{array}$ & $\begin{array}{l}\text { Aperture diameter } \\
\text { Thermal/dynamic WFE } \\
\text { Line-of-sight jitter } \\
\mathrm{kg} / \mathrm{m} 2 \\
\$ / \mathrm{m} 2\end{array}$ & $\begin{array}{l}6.5 \mathrm{~m} \\
60 \mathrm{~nm} \mathrm{rms} \\
1.6 \mathrm{mas} \\
40 \mathrm{~kg} / \mathrm{m} 2 \\
\$ 4 \mathrm{M} / \mathrm{m} 2\end{array}$ & $\begin{array}{l}8 \mathrm{~m}(15 \text { to } 30 \mathrm{~m}) \\
<0.1 \mathrm{~nm} \mathrm{rms} \\
1 \mathrm{mas} \\
<20(\text { or } 400) \mathrm{kg} / \mathrm{m} 2 \\
<\$ 2 \mathrm{M} / \mathrm{m} 2\end{array}$ & 2011 & $\begin{array}{l}2020 \\
(30)\end{array}$ \\
\hline $\begin{array}{l}\text { LISA } \\
\text { NWTP }\end{array}$ & $\begin{array}{l}\text { Drag-Free Flying } \\
\text { Occulter Flying }\end{array}$ & $\begin{array}{l}\text { Residual accel } \\
\text { Range } \\
\text { Lateral alignment }\end{array}$ & $3 \times 10^{-14} \mathrm{~m} / \mathrm{s}^{2} / \sqrt{\mathrm{Hz}}$ & $\begin{array}{l}3 \times 10^{-15} \mathrm{~m} / \mathrm{s}^{2} / \sqrt{\mathrm{Hz}} \\
10,000 \text { to } 80,000 \mathrm{~km} \\
\pm 0.7 \mathrm{~m} \text { wrt LOS }\end{array}$ & 2011 & 2016 \\
\hline $\begin{array}{l}\text { NWTP } \\
\text { Push }\end{array}$ & $\begin{array}{l}\text { Formation flying: } \\
\text { Sparse \& Interferometer }\end{array}$ & $\begin{array}{l}\text { Position/pointing } \\
\text { \#; Separation }\end{array}$ & $\begin{array}{l}5 \mathrm{~cm} / 6.7 \operatorname{arcmin} \\
2 ; 2 ; 2 \mathrm{~m}\end{array}$ & $5 ; 15-400-\mathrm{m}$ & 2011 & 2020 \\
\hline $\begin{array}{l}\text { LISA } \\
\text { Push }\end{array}$ & $\begin{array}{l}\text { Gravity wave sensor } \\
\text { Atomic interferometer }\end{array}$ & $\begin{array}{l}\text { Spacetime Strain } \\
\text { Bandpass }\end{array}$ & N/A & $\begin{array}{l}1 \times 10^{-21} / \sqrt{\mathrm{Hz}}, 0.1- \\
100 \mathrm{mHZ}\end{array}$ & 2013 & 2019 \\
\hline Various & Communication & Bits per sec & & Terra bps & & 2014 \\
\hline
\end{tabular}




\section{Technology Area Breakdown Structure (TABS)}

Technology needs for each SMD area were deconstructed into broad categories.

For example, many missions require new or improved detectors.

These broad categories were condensed into 3 groups:

Remote Sensing Instruments/Sensors,

Observatories, and

In-situ Instruments/Sensors.

and organized into a 4-level TABS. 


\section{TA8: Technology Area Breakdown Structure}

\subsection{Science Instruments, Observatories \& Sensor Systems}

8.1 Remote Sensing

Instruments/Sensors

\section{(8.1.1)}

Detectors and Focal Planes

8.1.1.1 Large Format Arrays

8.1.1.2 Spectral Detectors

8.1.1.3 Polarization Sensitive Det.

8.1.1.4 Photon-Counting Det.

8.1.1.5 Radiation-Hardened Det.

8.1.1.6 Sub-Kelvin High-Sensitivity Det

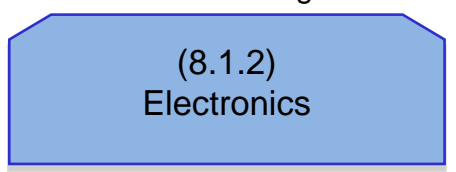

8.1.2.1 Radiation Hardened

8.1.2.2 Low Noise

8.1.2.3 High Speed

\section{(8.1.3)}

Optical Components

8.1.3.1 Starlight Suppression

8.1.3.2 Active Wavefront control

8.1.3.3 Optical Components

8.1.3.4 Advanced Spectrometers/Instruments

\section{(8.1.4)}

Microwave \& Radio Transmitters \& Receivers

8.1.4.1 Integrated Radar T/R Modules

8.1.4.2 Integrated Radiometer Receivers

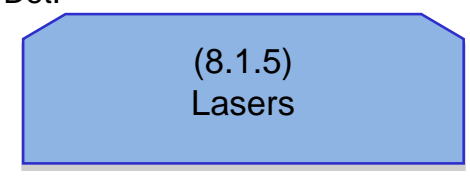

8.1.5.1 Pulsed Lasers

8.1.5.2 CW Lasers

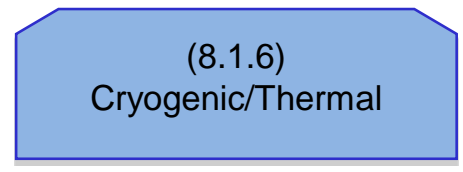

8.1.6.14-20K Cryo-Coolers for Space 8.1.6.2 Sub-Kelvin Coolers

\subsection{Observatories}

(8.2.1)

Large Mirror Systems

8.2.1.1 Grazing Incidence

8.2.1.2 Normal Incidence

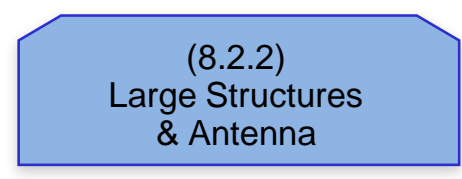

8.2.2.1 Passive Ultra-Stable Structures 8.2.2.2 Deployable/Assembled Tel. Support Structure and Antenna 8.2.2.3 Active Control

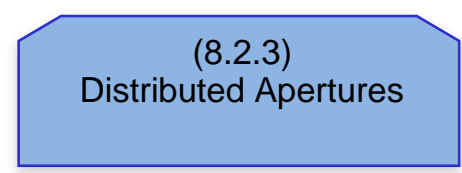

8.2.3.1 Formation Flying
8.3 In-Situ

Instruments/Sensors

\section{(8.3.1) \\ Particles}

8.3.1.1 Energetic Particle Det. (>30keV-NMeV)

8.3.1.2 Plasma Det. ( $<1 \mathrm{eV}-30 \mathrm{keV})$ 8.3.1.3 Magnetometers (DC \& $\mathrm{AC)}$

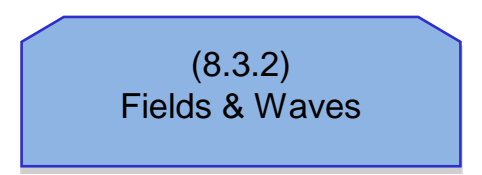

8.3.2.1 EM Field Sensors 8.3.2.2 Gravity-Wave Sensors

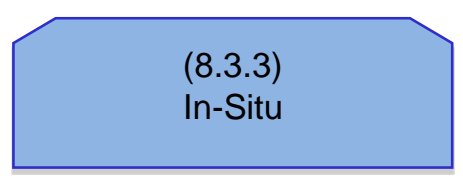

8.3.4.1 Sample Handling, Preparation, and Containment

8.3.4.2 Chemical and Mineral Assessment 8.3.4.3 Organic Assessment

8.3.4.4 Biological Detection \& Characterization 8.3.4.5 Planetary Protection 


\section{Technology Area Breakdown Structure (TABS)}

\section{Remote Sensing Instruments/Sensors:}

convert electromagnetic radiation (photons or waves) into science data or generate electromagnetic radiation (photons or waves);

typically require an observatory;

may be stand-alone sharing a common spacecraft bus

Observatory: collect, concentrate, and/or transmit photons.

In-situ Instruments/Sensors create science data from:

fields or waves (AC/DC electromagnetic, gravity, acoustic, seismic, etc); particles (charged, neutral, dust, etc.); or physical samples (chemical, biological, etc.). 


\section{Technology Area 8.2 Observatory}

Major challenges include:

$\mathrm{X}$-ray Grazing Incidence Mirror Systems

UV-Vis-IR Normal Incidence Mirror Systems

Large Ultra-stable Structures

Large Deployable/Assembled Structures

Control of Large Structures

Distributed Aperture / Formation flying

Technologies support 3 applications:

$\mathrm{X}$-ray astronomy,

UVOIR astronomy, and

Radio / microwave antenna.

Most important metric for all observatories is cost per square meter of aperture.

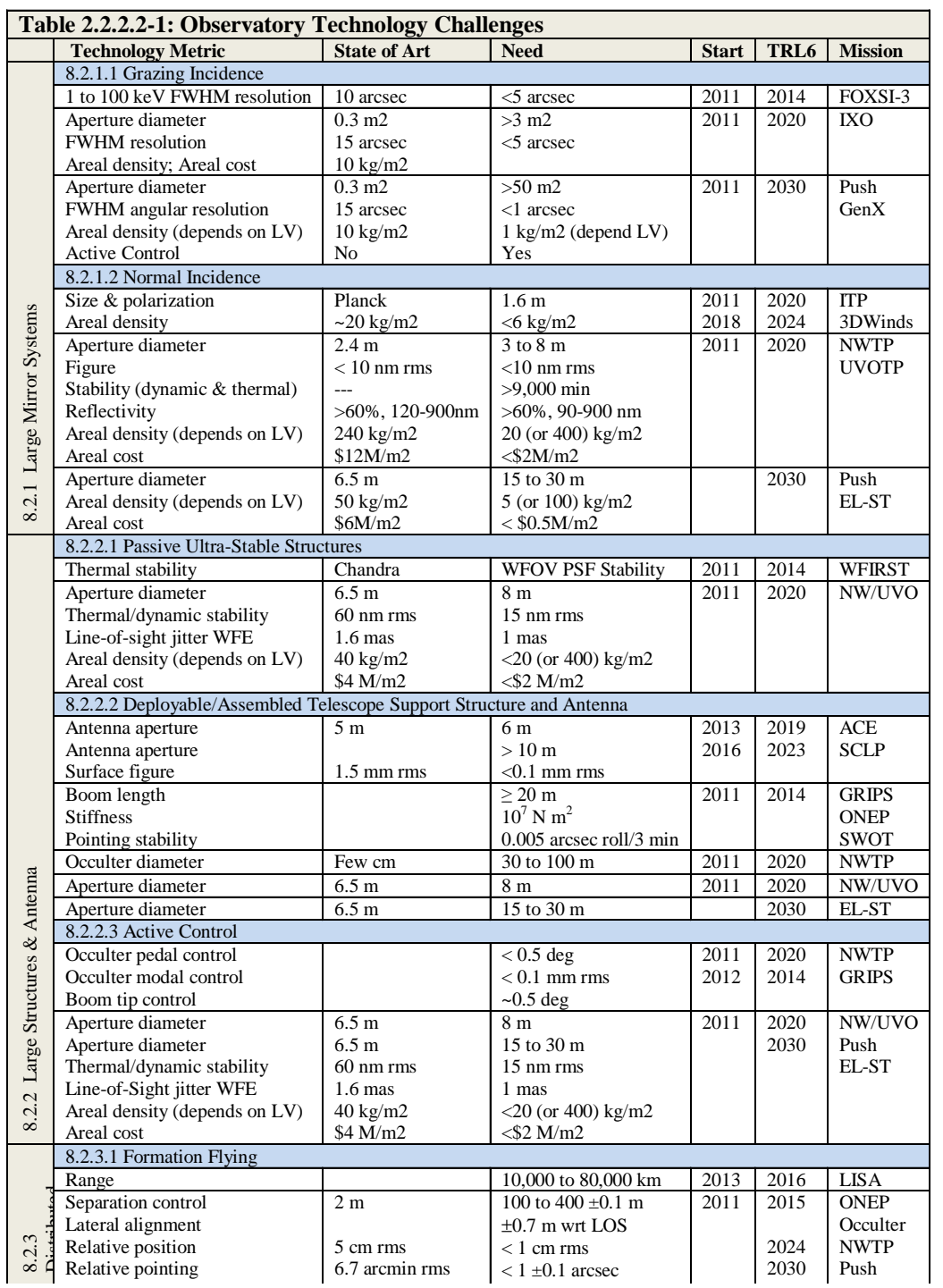


\begin{tabular}{|l}
\hline Table 2.2.2.2-1: Observatory Technology Challenges \\
\hline
\end{tabular}

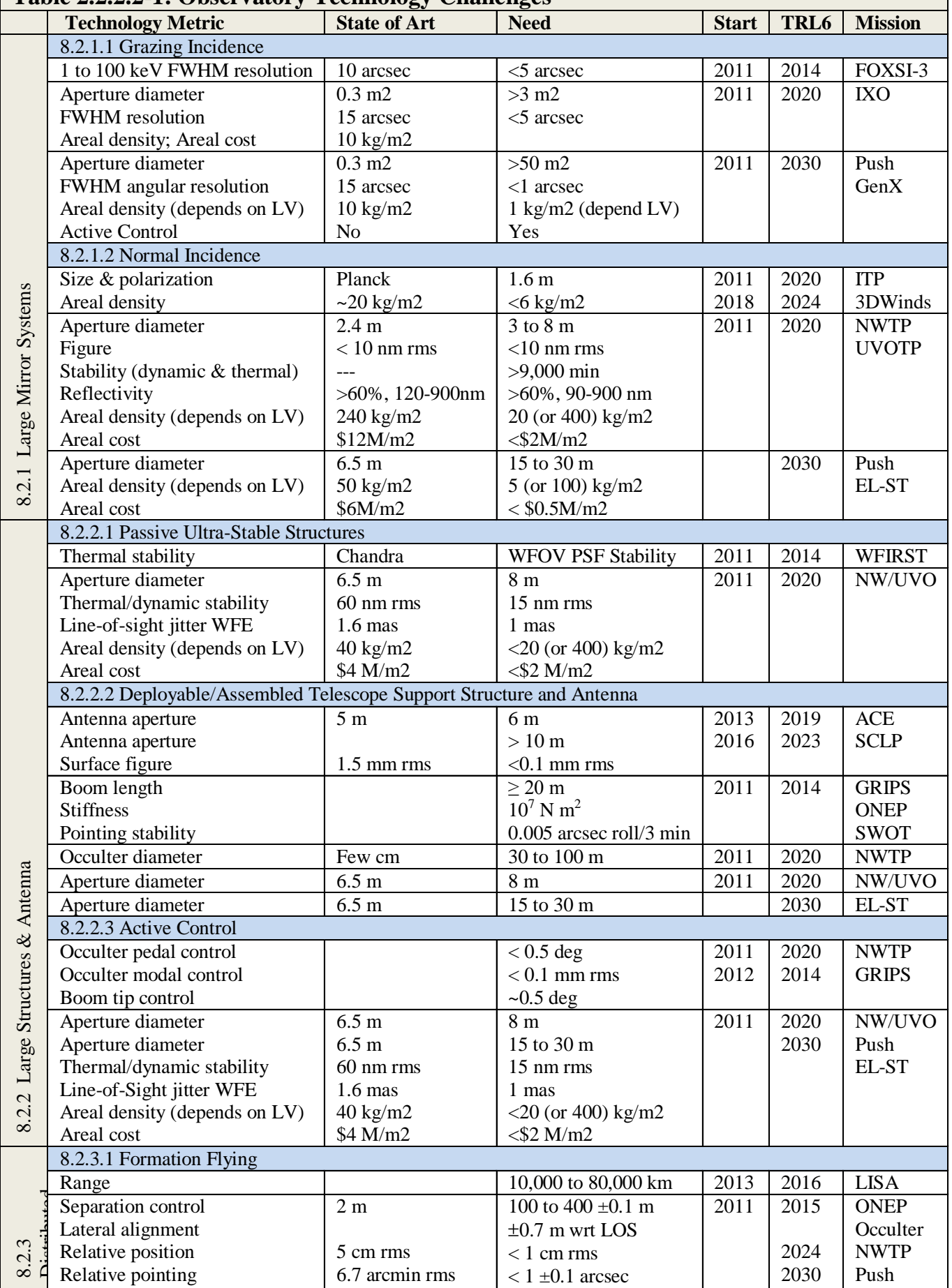




\section{Observatory Technology Needs}

Regardless of whether the incumbent is $0.5 \mathrm{~m}$ or $5 \mathrm{~m}$, the driving need is larger aperture with similar or better performance.

The technologies for achieving performance are

ability to manufacture and test large-mirror systems; ability to deposit large-aperture, uniform (amplitude \& polarization)

broadband high reflectance coatings;

ability to structurally hold mirror system in a stable, strain-free state under

the influence of anticipated dynamic and thermal stimuli; and, ability to create extra-large apertures via deployment, assembly, or formation flying

One non-telescope application is the manufacture, deployment, in-plane and formation-flying control of an external-occulting starshade to block starlight for exo-planet observation. 


\section{Other Technology Assessment Observatory Needs}

The ability to produce large aperture observatories depends upon advances in other technology assessment areas:

- volume and mass capacities of launch vehicles;

- validated performance models that integrate optical, mechanical, dynamic, and thermal models for telescopes, structures, instruments, and spacecraft to enable the design and manufacture of observatories whose performance requirements are too precise to be tested on the ground;

- new materials and design concepts to enable ultra-stable very large space structures;

- terabit communication; and

- autonomous rendezvous and docking for on-orbit assembly of very large structures. 


\section{Technology Development Roadmaps}

Development Roadmaps were developed for each TABS.

Roadmaps use TABS structure with direct traceability to identified mission needs for each Division.

Each technology need has specific maturity milestones (TRL-6).

Some technology needs have alternative pathway decision points.

Roadmaps explicitly includes 2020 \& 2030 Decadal Reviews

Explorer missions do not have explicit technology needs. 


\subsection{Observatories Roadmap}

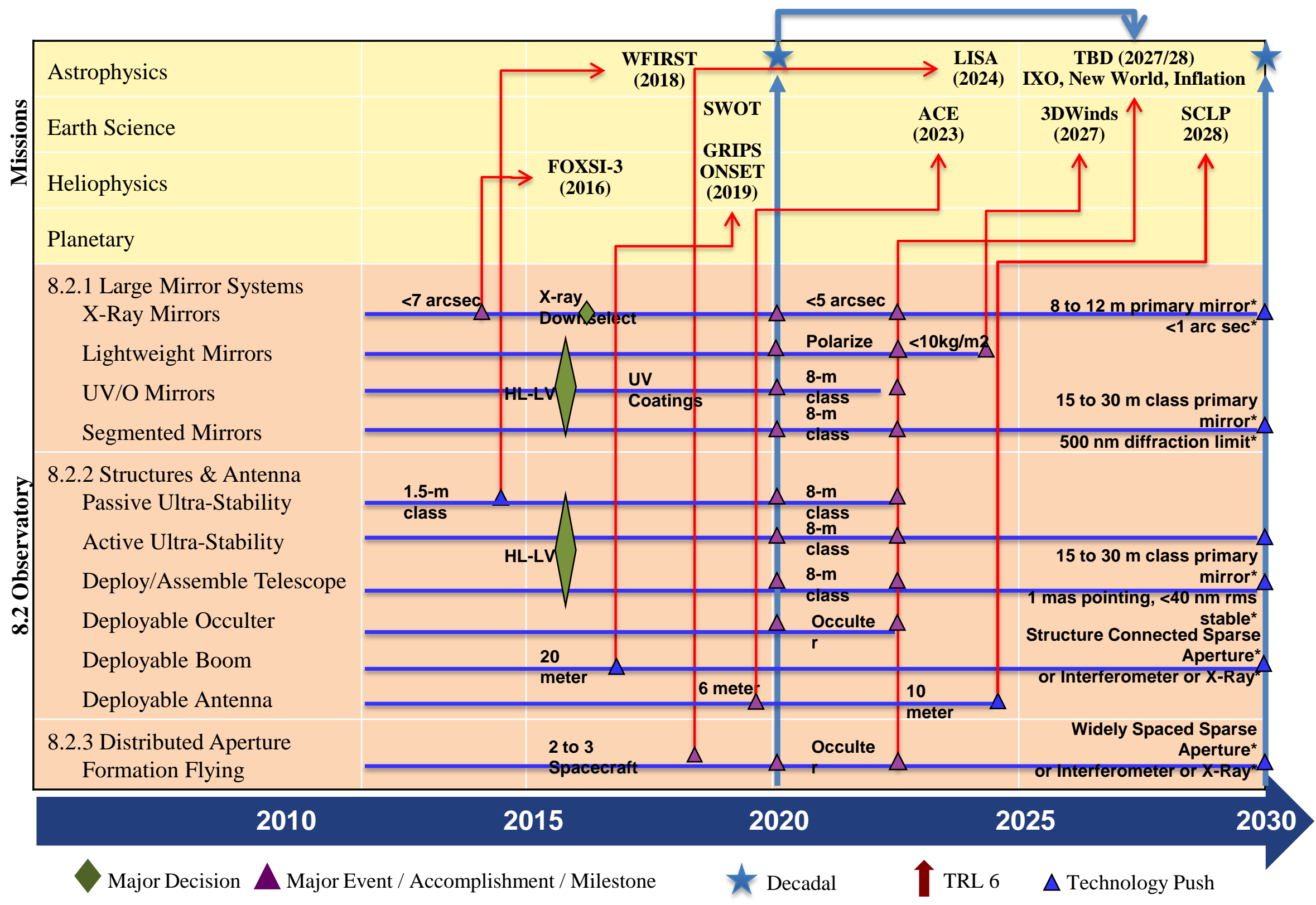




\section{Top Optical Manufacture \& Test Technical Challenges}

Near- \& mid-term investments to advance SOA by 2 to $10 \mathrm{X}$

Long-term investment to develop revolutionary capabilities

Must be balanced between short/mid and long-term.

Funding determined by competition \& peer review.

\begin{tabular}{|c|}
\hline Present to 2016 (Near Term) \\
\hline $\begin{array}{l}\text { Low-Cast, Large-Aperture Precisiom Mirrars } \\
\text { UV and optical lightweight mirrors, } 5 \text { to } 10 \mathrm{~nm} \mathrm{~ms},<\$ 2 \mathrm{M} / \mathrm{m} 2,<30 \mathrm{~kg} / \mathrm{m} 2 \\
\text { X-ray: }<5 \text { arc second resolution, }<\$ 0.1 \mathrm{M} / \mathrm{m} 2 \text { (surface normal space), }<3 \mathrm{~kg} / \mathrm{m} 2\end{array}$ \\
\hline 2017 to 2022 (Mid Term) \\
\hline $\begin{array}{l}\text { High-Contrast Exoplanet Technolngies } \\
\left.\text { High-contrast nulling and coronagraphy ( } 1 \times 10^{\wedge}-10 \text {, broadband); occulters ( } 30 \text { to } 100 \text { meters, }<0.1 \mathrm{~mm} \mathrm{rms}\right)\end{array}$ \\
\hline $\begin{array}{l}\text { Ultra-Stable Large Aperture LV/O Telescop ex } \\
>50 \mathrm{~m} 2 \text { aperture, }<10 \mathrm{~nm} \text { ms surface, }<1 \text { mas pointing }<15 \mathrm{~nm} \mathrm{~ms} \text { stability, }<\$ 2 \mathrm{M} / \mathrm{m} 2\end{array}$ \\
\hline 2023 and Beyond (Long Term) \\
\hline $\begin{array}{l}\text { Advanced Spatial Interfer ametric Imaging } \\
\text { Wide field imaging \& nulling to spectroscopically image an Earth-twin with }>32 \times 32 \text { pixels at } 20 \text { parsecs. }\end{array}$ \\
\hline $\begin{array}{l}\text { Many Spacecraft in Formation } \\
\text { Alignment \& positioning of } 20 \text { to } 50 \text { spacecratt distributed over } 10 \mathrm{~s} \text { (to } 1000 \mathrm{~s}) \text { of kilometers to nanometer precision with } \\
\text { milli-arc second pointing knowledge and stability }\end{array}$ \\
\hline
\end{tabular}




\section{Public Input}

The National Research Council received 63 SIOSS inputs.

$\begin{array}{ll}67 \%(42 / 63) & 8.1 \text { Remote Sensing Instruments/Sensors } \\ 14 \%(9 / 63) & 8.2 \text { Observatories } \\ 19 \%(12 / 63) & 8.3 \text { In-Situ Instruments/Sensors }\end{array}$

Most were corrections, clarifications \& amplifications of content already in the report.

Others pointed out technologies which the assessment team had missed - such as needs for Gamma Ray science.

Many were made 'collective' or 'consensus' inputs on behalf of individual science communities. 


\section{Public Inputs}

Science Instruments/Optical Components ( 9 inputs):

2 for WFSC to correct phase, intensity, amplitude \& polarization;

4 for components ranging from $\mathrm{x}$-ray \& UV diffraction gratings to narrow band spectral filters to electronically steerable laser beam;

3 microwave polarization feed horns \& planar antenna.

Observatory (9 inputs):

8m UVOIR and 4m UVOIR telescopes;

100 meter microwave antenna;

high reflectance UV coatings;

$\mathrm{x}$-ray and gamma ray imaging optics on 20 meter booms;

athermal telescope structures;

400 sq meter microwave phased array antenna structure;

300 meter booms for atom interferometers; and

distributed aperture systems. 


\section{Astrophysics Budget Planning}

The Decadal Survey recommended technology funding for:

1) Future missions at a level of $\sim 10 \%$ of NASA's anticipated budget for each mission to reduce risk and cost;

2) New Worlds, Inflation Probe and Future UV-Optical Space Capability Definition Technology Programs to prepare for missions beyond 2020; and

3) "General" technology to define, mature, and select approaches for future competed missions, and "Blue sky" technology to provide transformational improvements in capability and enable undreamed of missions. 


\section{Astrophysics Budget Planning}

Recommended Program and Technology Development

\begin{tabular}{|c|c|c|c|}
\hline Program & 10 -yr Total & $\underline{2012}$ & $\underline{2021}$ \\
\hline IXO & $\$ 200 \mathrm{M}$ & $\$ 4 \mathrm{M} / \mathrm{yr}$ & $\$ 30 \mathrm{M} / \mathrm{yr}$ \\
\hline Inflation Probe & $\$ 60$ to $\$ 200 \mathrm{M}$ & $\$ 4 \mathrm{M} / \mathrm{yr}$ & $\$ 30 \mathrm{M} / \mathrm{yr}$ \\
\hline New Worlds & $\$ 100$ to $\$ 200 \mathrm{M}$ & $\$ 4 \mathrm{M} / \mathrm{yr}$ & $\$ 30 \mathrm{M} / \mathrm{yr}$ \\
\hline UV-Optical & $\$ 40 \mathrm{M}$ & $\$ 2 \mathrm{M} / \mathrm{yr}$ & $\$ 10 \mathrm{M} / \mathrm{yr}$ \\
\hline
\end{tabular}

Recommended Augmentations to current \$40M/yr Investment

Advanced Tech $\$ 5 \mathrm{M} / \mathrm{yr}$

APRA

$\$ 20 \mathrm{M}$ (25\% increase)

Intermediate Tech $\$ 100 \mathrm{M}(\$ 2 \mathrm{M} / \mathrm{yr}$ now to $\$ 15 \mathrm{M} / \mathrm{yr}$ by 2021$)$

10 -yr Total is $\$ 1$ to $\$ 1.2 \mathrm{~B}$

Assume all Decadal Recommendations are for External Funding.

Assume NASA Internal Funding $=50 \%$ of External Funding

$\$ 60 \mathrm{M} / \mathrm{yr}=$ approx $200 \mathrm{FTEs} / \mathrm{yr}$ and $\$ 15 \mathrm{M} / \mathrm{yr}$ ODC 


\section{Observatory Budget Recommendations}

\$400M over 10-yrs to Industry/Academia for X-Ray mirrors, large UV mirrors, large structures, and formation flying:

$\begin{array}{llll}\text { Program } & 10 \text { year } & 2012 & 2021 \\ \text { IXO } & \$ 150 \mathrm{M} & \$ 3 \mathrm{M} / \mathrm{yr} & \$ 20 \mathrm{M} / \mathrm{yr} \\ \text { New World } & \$ 100 \mathrm{M} & \$ 2 \mathrm{M} / \mathrm{yr} & \$ 15 \mathrm{M} / \mathrm{yr} \\ \text { UVO } & \$ 20 \mathrm{M} & \$ 1 \mathrm{M} / \mathrm{yr} & \$ 5 \mathrm{M} / \mathrm{yr} \\ \text { General } & \$ 100 \mathrm{M} & \$ 10 \mathrm{M} / \mathrm{yr} & \$ 10 \mathrm{M} / \mathrm{yr} \\ \text { Earth/Helio } & \$ 30 \mathrm{M} & \$ 1 \mathrm{M} / \mathrm{yr} & \$ 5 \mathrm{M} / \mathrm{yr} \\ \text { TOTAL } & \$ 400 \mathrm{M} & \$ 17 \mathrm{M} / \mathrm{yr} & \$ 55 \mathrm{M} / \mathrm{yr}\end{array}$

NASA needs 75 FTE/yr \& \$6M/yr ODC for Tech Development 


\begin{tabular}{|c|c|c|c|c|c|c|c|c|c|c|c|}
\hline \multirow[t]{2}{*}{ ano } & \multirow[t]{2}{*}{ Technology Metric } & \multirow[t]{2}{*}{ State of Art } & \multirow[t]{2}{*}{ Need } & \multirow[t]{2}{*}{ TRL } & \multirow[t]{2}{*}{ TRL6 } & \multirow[t]{2}{*}{ Mission } & \multicolumn{3}{|c|}{ 10-yr External } & \multicolumn{2}{|c|}{ NASA Internal } \\
\hline & & & & & & & Total & FY12 & FY21 & FTE/yr & ODC/yr \\
\hline & \multicolumn{6}{|l|}{ 8.2 Observatory Technology } & $\$ 400 M$ & $\$ 19 M$ & $\$ 48 M$ & $75 / \mathrm{yr}$ & $\$ 5 \mathrm{M} / \mathrm{yr}$ \\
\hline \multirow{8}{*}{ 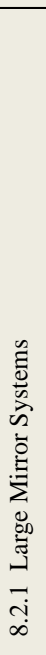 } & \multicolumn{6}{|l|}{ 8.2.1.1 Grazing Incidence } & $\$ 170 \mathrm{M}$ & $\$ 6 \mathrm{M}$ & $\$ 22 \mathrm{M}$ & 30 & $\$ 2 \mathrm{M}$ \\
\hline & 1 to $100 \mathrm{keV}$ FWHM resolution & $10 \operatorname{arcsec}$ & $<5 \operatorname{arcsec}$ & 5 & 2014 & FOXSI-3 & 5 & 2 & - & 6 & .5 \\
\hline & $\begin{array}{l}\text { Aperture diameter } \\
\text { FWHM resolution } \\
\text { Areal density; Areal cost }\end{array}$ & $\begin{array}{l}0.3 \mathrm{~m} 2 \\
15 \mathrm{arcsec} \\
10 \mathrm{~kg} / \mathrm{m} 2\end{array}$ & $\begin{array}{l}>3 \mathrm{~m} 2 \\
<5 \operatorname{arcsec}\end{array}$ & 3 & 2020 & IXO & 150 & 3 & 20 & 22 & 1.5 \\
\hline & $\begin{array}{l}\text { Aperture diameter } \\
\text { FWHM angular resolution } \\
\text { Areal density (depends LV) } \\
\text { Active Control }\end{array}$ & $\begin{array}{l}0.3 \mathrm{~m} 2 \\
15 \mathrm{arcsec} \\
10 \mathrm{~kg} / \mathrm{m} 2 \\
\text { No }\end{array}$ & $\begin{array}{l}>50 \mathrm{~m} 2 \\
<1 \operatorname{arcsec} \\
1 \mathrm{~kg} / \mathrm{m} 2 \text { (depend LV) } \\
\text { Yes }\end{array}$ & 2 & 2030 & $\begin{array}{l}\text { Push } \\
\text { GenX }\end{array}$ & 15 & 1 & 2 & 2 & - \\
\hline & \multicolumn{6}{|l|}{ 8.2.1.2 Normal Incidence } & $\$ 80 \mathrm{M}$ & $\$ 3 \mathrm{M}$ & $\$ 8 \mathrm{M}$ & 15 & $\$ 1 \mathrm{M}$ \\
\hline & $\begin{array}{l}\text { Size \& polarization } \\
\text { Areal density }\end{array}$ & $\begin{array}{l}\text { Planck } \\
\sim 20 \mathrm{~kg} / \mathrm{m} 2\end{array}$ & $\begin{array}{l}1.6 \mathrm{~m} \\
<6 \mathrm{~kg} / \mathrm{m} 2\end{array}$ & $\begin{array}{l}5 \\
5\end{array}$ & $\begin{array}{l}2020 \\
2024\end{array}$ & $\begin{array}{c}\text { ITP } \\
\text { 3DWinds }\end{array}$ & 5 & 1 & - & 3 & - \\
\hline & $\begin{array}{l}\text { Aperture diameter } \\
\text { Figure } \\
\text { Stability (dynamic \& thermal) } \\
\text { Reflectivity } \\
\text { Areal density (depends LV) } \\
\text { Areal cost }\end{array}$ & $\begin{array}{l}2.4 \mathrm{~m} \\
<10 \mathrm{~nm} \mathrm{rms} \\
--- \\
>60 \%, 120-900 \mathrm{~nm} \\
240 \mathrm{~kg} / \mathrm{m} 2 \\
\$ 12 \mathrm{M} / \mathrm{m} 2\end{array}$ & $\begin{array}{l}3 \text { to } 8 \mathrm{~m} \\
<10 \mathrm{~nm} \mathrm{rms} \\
>9,000 \mathrm{~min} \\
>60 \%, 90-900 \mathrm{~nm} \\
20(\text { or } 400) \mathrm{kg} / \mathrm{m} 2 \\
<\$ 2 \mathrm{M} / \mathrm{m} 2\end{array}$ & 4 & 2020 & $\begin{array}{l}\text { NWTP } \\
\text { UVOTP }\end{array}$ & 75 & 2 & 9 & 10 & 1 \\
\hline & $\begin{array}{l}\text { Aperture diameter } \\
\text { Areal density (depends LV) } \\
\text { Areal cost }\end{array}$ & $\begin{array}{l}6.5 \mathrm{~m} \\
50 \mathrm{~kg} / \mathrm{m} 2 \\
\$ 6 \mathrm{M} / \mathrm{m} 2\end{array}$ & $\begin{array}{l}15 \text { to } 30 \mathrm{~m} \\
5(\text { or } 100) \mathrm{kg} / \mathrm{m} 2 \\
<\$ 0.5 \mathrm{M} / \mathrm{m} 2\end{array}$ & 2 & 2030 & $\begin{array}{l}\text { Push } \\
\text { EL-ST }\end{array}$ & TBD & TBD & TBD & 2 & - \\
\hline \multirow{12}{*}{ 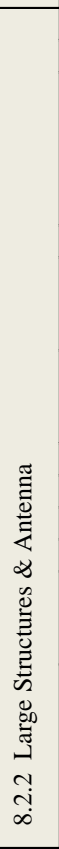 } & \multicolumn{6}{|c|}{ 8.2.2.1 Passive Ultra-Stable Structures } & $\$ 20 \mathrm{M}$ & $\$ 3 \mathrm{M}$ & $\$ 2 \mathrm{M}$ & 4 & $\$ 0.3 \mathrm{M}$ \\
\hline & Thermal stability & Chandra & WFOV PSF Stability & 5 & 2014 & WFIRST & 5 & 2 & - & 2 & - \\
\hline & $\begin{array}{l}\text { Aperture diameter } \\
\text { Thermal/dynamic stability } \\
\text { Line-of-sight jitter WFE } \\
\text { Areal density (depends LV) } \\
\text { Areal cost }\end{array}$ & $\begin{array}{l}6.5 \mathrm{~m} \\
60 \mathrm{~nm} \mathrm{rms} \\
1.6 \mathrm{mas} \\
40 \mathrm{~kg} / \mathrm{m} 2 \\
\$ 4 \mathrm{M} / \mathrm{m} 2 \\
\end{array}$ & $\begin{array}{l}8 \mathrm{~m} \\
15 \mathrm{~nm} \mathrm{rms} \\
1 \mathrm{mas} \\
<20(\text { or } 400) \mathrm{kg} / \mathrm{m} 2 \\
<\$ 2 \mathrm{M} / \mathrm{m} 2\end{array}$ & 3 & 2020 & NW/UVO & 15 & 1 & 2 & 2 & .3 \\
\hline & \multicolumn{6}{|c|}{ 8.2.2.2 Deployable/Assembled Telescope Support Structure and Antenna } & $\$ 50 \mathrm{M}$ & $\$ 4 \mathrm{M}$ & $\$ 6 \mathrm{M}$ & 10 & $\$ 0.7 \mathrm{M}$ \\
\hline & $\begin{array}{l}\text { Antenna aperture } \\
\text { Antenna aperture } \\
\text { Surface figure }\end{array}$ & $5 \mathrm{~m}$ & $\begin{array}{l}6 \mathrm{~m} \\
>10 \mathrm{~m} \\
<0.1 \mathrm{~mm} \mathrm{rms}\end{array}$ & $\begin{array}{l}5 \\
3\end{array}$ & $\begin{array}{l}2019 \\
2023\end{array}$ & $\begin{array}{l}\text { ACE } \\
\text { SCLP }\end{array}$ & 5 & 1 & - & 1 & - \\
\hline & $\begin{array}{l}\text { Boom length } \\
\text { Stiffness } \\
\text { Pointing stability }\end{array}$ & & $\begin{array}{l}\geq 20 \mathrm{~m} \\
10^{7} \mathrm{~N} \mathrm{~m}^{2} \\
0.005 \mathrm{arcsec} \mathrm{roll} / 3 \mathrm{~min}\end{array}$ & 5 & 2014 & $\begin{array}{l}\text { GRIPS } \\
\text { ONEP } \\
\text { SWOT }\end{array}$ & 5 & 2 & - & 3 & .3 \\
\hline & Occulter diameter & Few cm & 30 to $100 \mathrm{~m}$ & 2 & 2020 & NWTP & 20 & 1 & 3 & 3 & .3 \\
\hline & Aperture diameter & $6.5 \mathrm{~m}$ & $8 \mathrm{~m}$ & 4 & 2020 & NW/UVO & 20 & 1 & 3 & 2 & .1 \\
\hline & Aperture diameter & $6.5 \mathrm{~m}$ & 15 to $30 \mathrm{~m}$ & 2 & 2030 & EL-ST & TBD & TBD & TBD & 1 & - \\
\hline & \multicolumn{6}{|l|}{ 8.2.2.3 Active Control } & $\$ 30 \mathrm{M}$ & $\$ 2 \mathrm{M}$ & $\$ 4 \mathrm{M}$ & 6 & $\$ 0.4 \mathrm{M}$ \\
\hline & $\begin{array}{l}\text { Occulter pedal control } \\
\text { Occulter modal control } \\
\text { Boom tip control }\end{array}$ & & $\begin{array}{l}<0.5 \mathrm{deg} \\
<0.1 \mathrm{~mm} \mathrm{rms} \\
\sim 0.5 \mathrm{deg}\end{array}$ & $\begin{array}{l}3 \\
5\end{array}$ & $\begin{array}{l}2020 \\
2014\end{array}$ & $\begin{array}{l}\text { NWTP } \\
\text { GRIPS }\end{array}$ & 15 & 1 & 2 & 3 & .2 \\
\hline & $\begin{array}{l}\text { Aperture diameter } \\
\text { Aperture diameter } \\
\text { Thermal/dynamic stability } \\
\text { Line-of-Sight jitter WFE } \\
\text { Areal density (depends LV) } \\
\text { Areal cost }\end{array}$ & $\begin{array}{l}6.5 \mathrm{~m} \\
6.5 \mathrm{~m} \\
60 \mathrm{~nm} \mathrm{rms} \\
1.6 \mathrm{mas} \\
40 \mathrm{~kg} / \mathrm{m} 2 \\
\$ 4 \mathrm{M} / \mathrm{m} 2 \\
\end{array}$ & $\begin{array}{l}8 \mathrm{~m} \\
15 \text { to } 30 \mathrm{~m} \\
15 \mathrm{~nm} \mathrm{rms} \\
1 \mathrm{mas} \\
<20(\text { or } 400) \mathrm{kg} / \mathrm{m} 2 \\
<\$ 2 \mathrm{M} / \mathrm{m} 2\end{array}$ & $\begin{array}{l}3 \\
2\end{array}$ & $\begin{array}{l}2020 \\
2030\end{array}$ & $\begin{array}{l}\text { NW/UVO } \\
\text { Push } \\
\text { EL-ST }\end{array}$ & 15 & 1 & 2 & 3 & .2 \\
\hline \multirow[b]{3}{*}{ 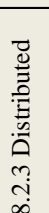 } & \multicolumn{6}{|l|}{ 8.2.3.1 Formation Flying } & $\$ 50 \mathrm{M}$ & $\$ 1 \mathrm{M}$ & $\$ 7 \mathrm{M}$ & 10 & $\$ 0.6 \mathrm{M}$ \\
\hline & Range & & 10,000 to $80,000 \mathrm{~km}$ & 5 & 2016 & LISA & TBD & TBD & TBD & 1 & - \\
\hline & $\begin{array}{l}\text { Separation control } \\
\text { Lateral alignment } \\
\text { Relative position } \\
\text { Relative pointing }\end{array}$ & $\begin{array}{l}2 \mathrm{~m} \\
5 \mathrm{~cm} \mathrm{rms} \\
6.7 \mathrm{arcmin} \mathrm{rms}\end{array}$ & $\begin{array}{l}100 \text { to } 400 \pm 0.1 \mathrm{~m} \\
\pm 0.7 \mathrm{~m} \mathrm{wrt} \mathrm{LOS} \\
<1 \mathrm{~cm} \mathrm{rms} \\
<1 \pm 0.1 \mathrm{arcsec}\end{array}$ & $\begin{array}{l}5 \\
3 \\
2\end{array}$ & $\begin{array}{l}2015 \\
2024 \\
2030\end{array}$ & $\begin{array}{l}\text { ONEP } \\
\text { Occulter } \\
\text { NWTP } \\
\text { Push }\end{array}$ & 50 & 1 & 7 & 9 & .6 \\
\hline
\end{tabular}




\begin{tabular}{|c|c|c|c|c|c|c|c|c|c|c|c|}
\hline & \multirow[t]{2}{*}{ Technology Metric } & \multirow[t]{2}{*}{ State of Art } & \multirow[t]{2}{*}{ Need } & \multirow[t]{2}{*}{ TRL } & \multirow[t]{2}{*}{ TRL6 } & \multirow[t]{2}{*}{ Mission } & \multicolumn{3}{|c|}{ 10-yr External } & \multicolumn{2}{|c|}{ NASA Internal } \\
\hline & & & & & & & Total & FY12 & FY21 & FTE/yr & ODC/yr \\
\hline & \multicolumn{6}{|l|}{8.2 Observatory Technology } & $\$ 400 M$ & $\$ 19 M$ & $\$ 48 M$ & $75 / \mathrm{yr}$ & $\$ 5 \mathrm{M} / \mathrm{yr}$ \\
\hline \multirow{8}{*}{ 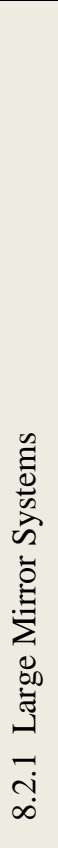 } & 8.2.1.1 Grazing Incidence & & & & & & $\$ 170 \mathrm{M}$ & $\$ 6 \mathrm{M}$ & $\$ 22 \mathrm{M}$ & 30 & $\$ 2 \mathrm{M}$ \\
\hline & 1 to $100 \mathrm{keV}$ FWHM resolution & $10 \operatorname{arcsec}$ & $<5 \operatorname{arcsec}$ & 5 & 2014 & FOXSI-3 & 5 & 2 & - & 6 & .5 \\
\hline & $\begin{array}{l}\text { Aperture diameter } \\
\text { FWHM resolution } \\
\text { Areal density; Areal cost }\end{array}$ & $\begin{array}{l}0.3 \mathrm{~m} 2 \\
15 \mathrm{arcsec} \\
10 \mathrm{~kg} / \mathrm{m} 2\end{array}$ & $\begin{array}{l}>3 \mathrm{~m} 2 \\
<5 \operatorname{arcsec}\end{array}$ & 3 & 2020 & IXO & 150 & 3 & 20 & 22 & 1.5 \\
\hline & $\begin{array}{l}\text { Aperture diameter } \\
\text { FWHM angular resolution } \\
\text { Areal density (depends LV) } \\
\text { Active Control }\end{array}$ & $\begin{array}{l}0.3 \mathrm{~m} 2 \\
15 \mathrm{arcsec} \\
10 \mathrm{~kg} / \mathrm{m} 2 \\
\text { No }\end{array}$ & $\begin{array}{l}>50 \mathrm{~m} 2 \\
<1 \mathrm{arcsec} \\
1 \mathrm{~kg} / \mathrm{m} 2 \text { (depend LV) } \\
\text { Yes }\end{array}$ & 2 & 2030 & $\begin{array}{l}\text { Push } \\
\text { GenX }\end{array}$ & 15 & 1 & 2 & 2 & - \\
\hline & \multicolumn{6}{|l|}{ 8.2.1.2 Normal Incidence } & $\$ 80 \mathrm{M}$ & $\$ 3 \mathrm{M}$ & $\$ 8 \mathrm{M}$ & 15 & $\$ 1 \mathrm{M}$ \\
\hline & $\begin{array}{l}\text { Size \& polarization } \\
\text { Areal density }\end{array}$ & $\begin{array}{l}\text { Planck } \\
\sim 20 \mathrm{~kg} / \mathrm{m} 2\end{array}$ & $\begin{array}{l}1.6 \mathrm{~m} \\
<6 \mathrm{~kg} / \mathrm{m} 2\end{array}$ & $\begin{array}{l}5 \\
5\end{array}$ & $\begin{array}{l}2020 \\
2024\end{array}$ & $\begin{array}{c}\text { ITP } \\
\text { 3DWinds }\end{array}$ & 5 & 1 & - & 3 & - \\
\hline & $\begin{array}{l}\text { Aperture diameter } \\
\text { Figure } \\
\text { Stability (dynamic \& thermal) } \\
\text { Reflectivity } \\
\text { Areal density (depends LV) } \\
\text { Areal cost }\end{array}$ & $\begin{array}{l}2.4 \mathrm{~m} \\
<10 \mathrm{~nm} \mathrm{rms} \\
--- \\
>60 \%, 120-900 \mathrm{~nm} \\
240 \mathrm{~kg} / \mathrm{m} 2 \\
\$ 12 \mathrm{M} / \mathrm{m} 2 \\
\end{array}$ & $\begin{array}{l}3 \text { to } 8 \mathrm{~m} \\
<10 \mathrm{~nm} \mathrm{rms} \\
>9,000 \mathrm{~min} \\
>60 \%, 90-900 \mathrm{~nm} \\
20(\text { or } 400) \mathrm{kg} / \mathrm{m} 2 \\
<\$ 2 \mathrm{M} / \mathrm{m} 2 \\
\end{array}$ & 4 & 2020 & $\begin{array}{l}\text { NWTP } \\
\text { UVOTP }\end{array}$ & 75 & 2 & 9 & 10 & 1 \\
\hline & $\begin{array}{l}\text { Aperture diameter } \\
\text { Areal density (depends LV) } \\
\text { Areal cost }\end{array}$ & $\begin{array}{l}6.5 \mathrm{~m} \\
50 \mathrm{~kg} / \mathrm{m} 2 \\
\$ 6 \mathrm{M} / \mathrm{m} 2\end{array}$ & $\begin{array}{l}15 \text { to } 30 \mathrm{~m} \\
5(\text { or } 100) \mathrm{kg} / \mathrm{m} 2 \\
<\$ 0.5 \mathrm{M} / \mathrm{m} 2\end{array}$ & 2 & 2030 & $\begin{array}{l}\text { Push } \\
\text { EL-ST }\end{array}$ & TBD & TBD & TBD & 2 & - \\
\hline
\end{tabular}




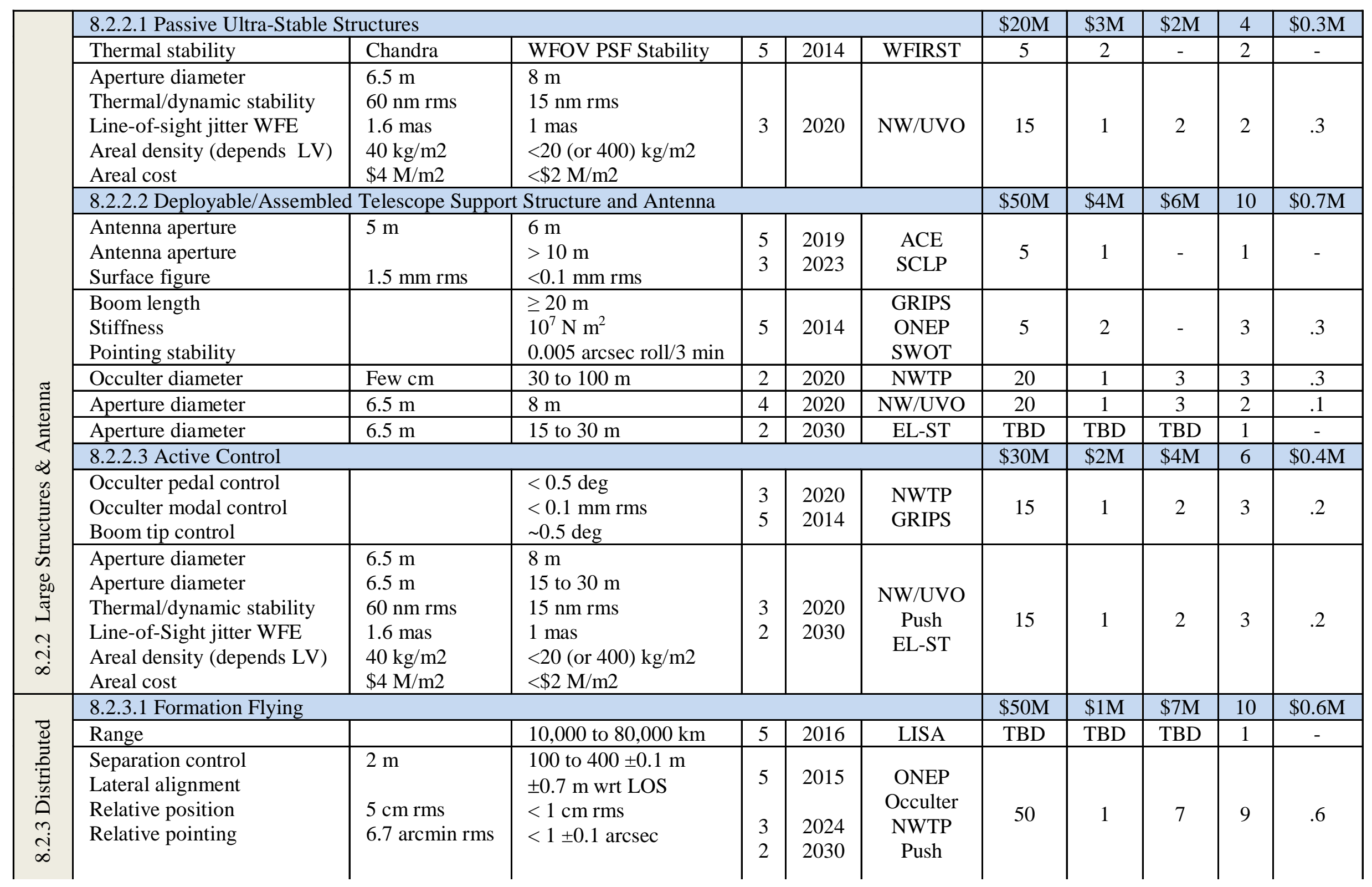




\section{Conclusion}

Technology advancement is required to enable NASA's high priority missions of the future.

To prepare for those missions requires a roadmap of how to get from the current state of the art to where technology needs to be in $5,10,15$ and 20 years.

SIOSS identifies where substantial enhancements in mission capabilities are needed and provides strategic guidance for the agency's budget formulation and prioritization process.

The initial report was presented to the NRC in Oct 2010 (http://www.nasa.gov/offices/oct/home/roadmaps/index.html). And, the NRC review report is expected in late summer 2011. 